\title{
Changes in anti-nutrient, phytochemical, and micronutrient contents of different processed rubber (Hevea brasiliensis) seed meals
}

\author{
Chidinma Agbai ${ }^{\text {Equal first author, } 1}$, Ijeoma A. Olawuni ${ }^{\text {Equal first author, } 1 \text {, Chigozie E Ofoedu }}{ }^{\text {Corresp., 1, }}{ }^{2}$, Chidi J. Ibeabuchi ${ }^{1}$, Charles \\ Odilichukwu R. Okpala ${ }^{\text {Corresp., } 3}{ }^{\text {, Ivan Shorstkii }}{ }^{4}$, Małgorzata Korzeniowska ${ }^{3}$ \\ ${ }^{1}$ Department of Food Science and Technology, School of Engineering and Engineering Technology, Federal University of Technology, Owerri, Owerri, Imo, \\ Nigeria

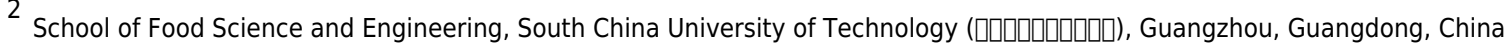 \\ 3 Department of Functional Food Products Development, Faculty of Biotechnology and Food Science, Wrocław University of Environmental and Life \\ Sciences, Wroclaw, Poland \\ 4 Department of Technological Equipment and Life-Support Systems, Kuban State Technological University, Krasnodar, Russian Federation \\ Corresponding Authors: Chigozie E Ofoedu, Charles Odilichukwu R. Okpala \\ Email address: chigozie.ofoedu@futo.edu.ng, charlesokpala@gmail.com
}

Rubber (Hevea brasiliensis) is a perennial plant crop grown in many parts of Africa, South East Asia, South America, especially within the hot and humid climatic regions. Rubber seed, either as feed or food, is a useful raw material to produce edible oil and protein. Despite the huge quantity of rubber seeds produced in Nigeria and its potential as a protein source, rubber seeds still appear neglected and under-utilised as feed/food given its perception as inedible and toxic given the high concentration of cyanogenic glycoside. Therefore, the quest for effective processing technique(s) that would enhance its food use application is very fitting. This current study was directed to determine the changes in anti-nutrient, phytochemical, and micronutrient contents of different processed rubber seed meals. Specifically, the rubber seeds underwent processing, which employed boiling and the combined action of boiling and fermentation methods that brought about three seed meal flour groups, i.e., raw (RRSM), boiled (BRSM), and fermented (FRSM) seed meals. These were subsequently analysed for anti-nutrient /phytochemical (oxalate, phytate, tannin, phenols, saponin, hydrogen cyanide (HCN), alkaloids, flavonoids, and trypsin inhibitors), and micronutrient (which involved minerals [magnesium, phosphorus, calcium, iron, zinc, potassium, sodium, manganese, lead and selenium] and vitamin [vitamin B1, B2, B3, C, E, and beta carotene]) contents. The results showed that the processing methods used to achieve the RRSM, BRSM, and FRSM, reduced the antinutrients (phytate, tannin, and oxalate) below the acceptable limits, and the HCN below the toxic levels. Importantly, the processing methods herein have not yet succeeded in removing $\mathrm{HCN}$ in the (processed) rubber seed meals, but can be seen to be heading toward the right direction. The FRSM obtained significantly lower $(p<0.05)$ anti- 
nutrient/phytochemical, but significantly higher $(p<0.05)$ mineral contents, compared with the other groups (RRSM and BRSM), except for flavonoids that obtained a $30 \%$ increase over the BRSM. Some mineral and vitamin contents could be lost in the BRSM compared to the others (RRSM and FRSM) in this study. Additionally, the FRSM obtained higher vitamin contents, after those of RRSM. Overall, the combined action of boiling and fermentation should be recommended for the proper utilisation of rubber seed as food/feed. 
1 To be accepted at PeerJ

2

3 Changes in anti-nutrient, phytochemical, and

4 micronutrient contents of different processed rubber 5 (Hevea brasiliensis) seed meals

6

Chidinma M. Agbai ${ }^{1}$, Ijeoma A. Olawuni ${ }^{1}$, Chigozie E. Ofoedu ${ }^{1,2 *}$ Chidi J. Ibeabuchi ${ }^{1}$, Charles Odilichukwu R. Okpala ${ }^{3 *}$, Ivan Shorstkii ${ }^{4}$, and Małgorzata Korzeniowska ${ }^{3}$

${ }^{1}$ Department of Food Science and Technology, School of Engineering and Engineering Technology, Federal University of Technology, Owerri, P.M.B. 1526, Nigeria 2School of Food Science and Engineering, South China University of Technology, Guangzhou, Guangdong, 510640, China.

${ }^{3}$ Department of Functional Food Products Development, Faculty of Biotechnology and Food Science, Wrocław University of Environmental and Life Sciences, 51-630 Wrocław, Poland

${ }^{4}$ Department of Technological Equipment and Life-Support Systems, Kuban State Technological University, Krasnodar, Russian Federation

Correspondence: chigozie.ofoedu@futo.edu.ng (CE Ofoedu); charlesokpala@gmail.com (COR Okpala) 


\section{ABSTRACT}

Rubber (Hevea brasiliensis) is a perennial plant crop grown in many parts of Africa, South East Asia, South America, especially within the hot and humid climatic regions. Rubber seed, either as feed or food, is a useful raw material to produce edible oil and protein. Despite the huge quantity of rubber seeds produced in Nigeria and its potential as a protein source, rubber seeds still appear neglected and under-utilised as feed/food given its perception as inedible and toxic given the high concentration of cyanogenic glycoside. Therefore, the quest for effective processing technique(s) that would enhance its food use application is very fitting. This current study was directed to determine the changes in anti-nutrient, phytochemical, and micronutrient contents of different processed rubber seed meals. Specifically, the rubber seeds underwent processing, which employed boiling and the combined action of boiling and fermentation methods that brought about three seed meal flour groups, i.e., raw (RRSM), boiled (BRSM), and fermented (FRSM) seed meals. These were subsequently analysed for anti-nutrient /phytochemical (oxalate, phytate, tannin, phenols, saponin, hydrogen cyanide ( $\mathrm{HCN})$, alkaloids, flavonoids, and trypsin inhibitors), and micronutrient (which involved minerals [magnesium, phosphorus, calcium, iron, zinc, potassium, sodium, manganese, lead and selenium] and vitamin [vitamin B1, B2, B3, C, E, and beta carotene]) contents. The results showed that the processing methods used to achieve the RRSM, BRSM, and FRSM, reduced the anti-nutrients (phytate, tannin, and oxalate) below the acceptable limits, and the HCN below the toxic levels. Importantly, the processing methods herein have not yet succeeded in removing $\mathrm{HCN}$ in the (processed) rubber seed meals, but can be seen to be heading toward the right direction. The FRSM obtained significantly lower $(p<0.05)$ anti-nutrient/phytochemical, but significantly higher $(p<0.05)$ mineral contents, compared with the other groups (RRSM and BRSM), except for flavonoids that obtained a $30 \%$ increase over the BRSM. Some mineral and vitamin contents could be lost in the BRSM compared to the others (RRSM and FRSM) in this study. Additionally, the FRSM obtained higher vitamin contents, after those of RRSM. Overall, the combined action of boiling and fermentation should be recommended for the proper utilisation of rubber seed as food/feed.

Keywords: anti-nutrients; boiling; fermentation; Hevea brasiliensis; minerals; phytochemicals; seed meals; vitamins

\section{INTRODUCTION}

Conventional agriculture has made cereal, legume, pulse, and meat food protein products possible for human consumption. Unfortunately, today's sky-rocketing demand for protein-rich meals has put the conventional production of the above-mentioned (agrofood products) at risk, which has arisen owed to the inability of conventional production to cope, given by the increases in today's global (animal/human) population. Importantly, over $8.9 \%$ of the global human population which suffers from hunger and malnutrition especially protein deficiency, has been mainly attributable to the high cost of meat and protein-rich foods (Medek et al., 2017; Drago, 2017; Redondo et al., 2019; FAO, IFAD, UNICEF, WFP \& WHO, 2020). It is equally true that such increases in the global (animal/human) population bring about the concept of food insecurity. A sustainable nutrient-dense agrofood source is therefore achieved through increased 
68 research to develop healthy, quality, and safe (agrofood) products, particularly those

69 that can be made from more eco-friendly processes, which would essentially be

70 adapted to the variants of consumers' needs (Bigliardi \& Galanakis, 2020). A potential

71 solution can be to identify a nutrient-dense agrofood source that is cheap, available, and

72 less competed by animal, man, and industry (Akinmutimi, 2004).

Rubber (Hevea brasiliensis) is a perennial plant crop grown in many parts of Africa, South East Asia, South America, and regions with hot and humid climates. According to the Nigerian Rubber Research Institute, about 28,000 tonnes of rubber seeds are estimated from 354,000 ha of rubber plantations in Nigeria (FAOSTAT, 2019; Maliki \& Ifijen, 2020). Rubber tree is commercially grown in Nigeria for latex production, while the abundant seeds are under-exploited and wasting. Rubber seed meal has been reported to have considerable amounts of absorbable nutrients than many conventional seed meals (Aguihe et al, 2017; Udo, Ekpo \& Ahamefula, 2018) as high amount of protein content (19.40 - 30.68\%), crude fat (42.50 - 54.17\%), and carbohydrates (11.58 - $29 \%$ ) had been reported from earlier studies (Onwurah et al., 2010; Sharma, Saha \& Saha, 2014; Hossain, Karim, Alam \& Nath, 2015; Suprayudi et al., 2015; Lalabe, Olusiyi \& Afolabi, 2017; Agbai et al., 2020). This is also similar to the composition of some conventional seed meals such as soybean meal and cottonseed meal as reported by Tang et al., (2012) and Ma et al., (2019). As a result of the enormous potential of rubber seed as an oil and protein-rich source, multiple studies have reported extraction of oil from rubber seed (Morshed et al., 2011; Yusup \& Wai, 2016; Widyarani et al., 2017) for biodiesel production and other purposes, and derivation of protein isolate from rubber seed meal (particularly after oil separation) (Fawole et al., 2016a; Widyarani et al., 2017; Fawole et al., 2016b) for protein valorization, feed, and food uses. Therefore, this nutrient-dense (rubber seed meal) product can influence food composition by proportion incorporation during product formulation/development. Besides rubber seed being processed and consumed in some regions of Indonesia as a staple diet (Lukman et al., 2018) and in Malaysia as their daily dish (Asam rong) (Siti et al., 2013), there are continued hindrances to its utilization as food in many parts of the world, largely due to the toxicity of the rubber seed, given by the high concentration of anti-nutrients (phytochemicals) and cyanogenic glycoside. Despite the interference offered by anti-nutrients (phytochemical compounds) in nutrient absorption, which act to reduce the nutrient intake, digestion, and utilization (Popova and Mihaylova, 2019), the exposure to cyanide from intentional or unintentional consumption of food with a high dose of cyanogenic glycoside could lead to acute intoxication characterized by growth retardation and neurological symptoms resulting from tissue damage in the central nervous system (Bolarinwa et al., 2016).

There is evidence in relevant literature that rubber seed products have been of interest to many researchers. Examples of areas of focus have included nutrient value of rubber seed flour (Onwurah et al., 2010), processing effects on nutrient composition of rubber seed meal (Udo, Ekpo \& Ahamefule, 2018), and basic properties of crude rubber seed oil (Yusup \& Khan, 2010). Indeed, the rubber seed remains posited with a high content of cyanogenic glycosides (Eka, Tajul Aris \& Wan Nadiah, 2010; Oluodo, Huda \& Komilus, 2018) like those associated with cassava tubers. Through processing and treatment methods, cyanogenic glycoside can either be 
113 eliminated or reduced successfully, and examples applied in the context of rubber seed

114 include heat treatments (toasting, boiling, roasting), storage (2 - 4 months) at ambient

115 temperature (Eka, Tajul \& Wan, 2010; Udo et al., 2016; Oluodo, Huda \& Komilus, 2018;

116 Farr et al., 2019), enzymatic reaction, absorbent (Oluodo et al., 2018), and fermentation

117 (Syahruddin, Herawaty \& Ningrat, 2014; Oluodo et al., 2018; Farr et al., 2019). There is

118 a high chance that, through such (above-mentioned) processing treatment methods,

119 different grades of rubber seed meals can be actualised. However, despite these

120 various processing methods previously used to treat rubber seed, there is still paucity of

121 relevant literature particularly on how the combination of treatment methods, for

122 instance, heat treatments and fermentation, could influence the chemical components of

123 rubber seed meal. It is possible that, through such combined treatment methods, both

124 processors and product developers on (seed meal) selection could achieve promising

125 quality output, which could enhance and strengthen the edibility of processed rubber

126 seed meals. To supplement existing information, therefore, this current study

127 investigated the changes in anti-nutrient, phytochemical, and micronutrient contents of

128 different processed rubber seed meals. It is expected that the combined action of

129 boiling/heat treatment and fermentation process would help elevate the edibility and

130 resultant quality of the rubber seed product.

\section{MATERIALS AND METHODS}

\section{Schematic overview of the experimental program}

The experimental program schematically depicting the key steps, from the procurement of rubber seed samples to laboratory analyses of (rubber seed) meals, is shown in Figure 1. In particular, this current research was designed to determine the changes in anti-nutrient, phytochemical, and micronutrient contents of different processed rubber seed meals. Specifically, the rubber seeds underwent processing, which brought about three seed meal flour groups: a) raw rubber seed meal (RRSM); b) boiled rubber seed meal (BRSM); c) fermented rubber seed meal (FRSM).

Subsequently, the emergent rubber seed meal flours were analyzed for anti-nutrients, micronutrients, and phytochemicals content.

\section{Chemicals and reagents}

All chemicals and reagents (i.e., Acetic acid $\left(\mathrm{CH}_{3} \mathrm{COOH}\right)$, Alcoholic potassium hydroxide $\left(\mathrm{C}_{2} \mathrm{H}_{7} \mathrm{KO}_{2}\right)$, Ammonia solution $\left(\mathrm{NH}_{4} \mathrm{OH}\right)$, Aqueous ethanol solution $\left(\mathrm{C}_{2} \mathrm{H}_{5} \mathrm{OH}\right)$, Copper (II) sulphate $\left(\mathrm{CuSO}_{4}\right)$, Diethyl ether $\left(\mathrm{C}_{2} \mathrm{H}_{5} \mathrm{OH}\right)$, Erichrome black $\mathrm{T}$ $\left(\mathrm{C}_{20} \mathrm{H}_{12} \mathrm{~N}_{3} \mathrm{O}_{7} \mathrm{SNa}\right)$, Ethanolic sodium hydroxide $\left(\mathrm{C}_{2} \mathrm{H}_{7} \mathrm{NaO}_{2}\right)$, Ethyl acetate $\left(\mathrm{CH}_{3} \mathrm{COOC}_{2} \mathrm{H}_{5}\right)$, Ethylenediaminetetra acetic acid (EDTA) $\left(\mathrm{C}_{10} \mathrm{H}_{14} \mathrm{~N}_{2} \mathrm{Na}_{2} \mathrm{O}_{8}\right)$, Ferric chloride $\left(\mathrm{FeCl}_{3}\right)$, Folin ciocalteau reagent (Phosphomolybdate and phosphotungstate mixture), Folin Denis reagent (Phosphomolybdate and phosphotungstate mixture), Gallic acid solution $\left(\mathrm{C}_{6} \mathrm{H}_{2}(\mathrm{OH})_{3} \mathrm{COOH}\right)$, Hydrochloric acid $(\mathrm{HCl})$, Hydrogen peroxide $\left(\mathrm{H}_{2} \mathrm{O}_{2}\right)$, Hydrogen sulphate $\left(\mathrm{H}_{2} \mathrm{SO}_{4}\right)$, Hydroxylamine hydrochloride $\left(\mathrm{NH}_{2} \mathrm{OH} . \mathrm{HCl}\right), \mathrm{N}$ hexane $\left(\mathrm{C}_{6} \mathrm{H}_{14}\right)$, $\mathrm{N}$-butanol $\left(\mathrm{C}_{4} \mathrm{H}_{9} \mathrm{OH}\right)$, $\mathrm{N}$ - $\alpha$-benzoyl-DLarginine-P-nitroanilide (BAPA), Phosphorus colour reagent (vanadomobydate solution), Picrate, Potassium cyanide $(\mathrm{KCN})$, Potassium dichromate $\left(\mathrm{K}_{2} \mathrm{Cr}_{2} \mathrm{O}_{7}\right)$, Potassium iodide solution (KI), Potassium permanganate solution $\left(\mathrm{KMnO}_{4}\right)$, Potassium chloride $(\mathrm{KCl})$, Sodium carbonate solution 
$156\left(\mathrm{Na}_{2} \mathrm{CO}_{3}\right)$, Sodium chloride $(\mathrm{NaCl})$, Sodium cyanide $(\mathrm{NaCN})$, Sodium hydroxide solution

$157(\mathrm{NaOH})$, Sodium potassium ferrocyanide $\left(\mathrm{Na}_{4} \mathrm{Fe}(\mathrm{CN})_{6}\right)$, Sodium sulphate $\left(\mathrm{Na}_{2} \mathrm{SO}_{4}\right)$,

158 Solochrome dark blue indicator $\left(\mathrm{C}_{20} \mathrm{H}_{13} \mathrm{~N}_{2} \mathrm{O}_{5} \mathrm{SNa}\right)$, Standard phosphorus solution

$159\left(\mathrm{~K}_{2} \mathrm{HPO}_{4}\right), \alpha-\alpha$-dipyridyl., and Standard tannin acid solution $\left(\mathrm{C}_{76} \mathrm{H}_{56} \mathrm{O}_{46}\right)$ used in this

160 current study were of analytical grade standard.

161

162

163

164

165

166

167

168

169

170

171

172

173

174

175

176

177

178

179

180

181

182

183

184

185

186

187

188

189

190

191

192

193

194

195

196

197

198

199

200

\section{Processing of rubber seed meal samples}

Specifically, mature rubber seeds were collected from Nigerian Rubber Institute, Akwete, Abia state, Nigeria. Processing of rubber seed samples $(1 \mathrm{~kg})$ involved sorting, dehulling, washing of seeds, boiling and fermentation of rubber seeds, and were implemented at the Department of Food Science and Technology, Federal University of Technology - Owerri, Nigeria. The schematic diagram for the production process to generate the rubber seed meals is presented in Figure 2. As shown, the raw rubber seed meal (RRSM) was produced by drying rubber seeds in an oven (Genlab, England, Model M $30 \mathrm{C}, \mathrm{S} / \mathrm{N}$ 92B060) at $60^{\circ} \mathrm{C}$ followed by milling using a blender (KenWood Blender, Model BL330, UK) into a fine flour. The boiled rubber seed meal (BRSM) was produced by boiling the rubber seeds for 2 hours, followed by oven drying at $60{ }^{\circ} \mathrm{C}$ for 24 hours and dry milling into a fine flour. The fermented rubber seed meal (FRSM) was produced by wrapping 2 hours of boiled rubber seeds in already steam blanched plantain leaves. Subsequently, the wrapped sample was placed in a basket to ferment for 3 days at a temperature between $30-35^{\circ} \mathrm{C}$, followed by oven drying at $60{ }^{\circ} \mathrm{C}$ for 24 hours and dry milling into a fine flour. Flours obtained from raw and processed (boiled and fermented) rubber seed meals were tightly sealed in glass containers until further analysis.

\section{Anti-nutrient, micronutrients, and phytochemical measurements of different rubber seed meals}

Determination of some anti-nutrient, micronutrient, and phytochemical contents of rubber seed meals was conducted at the Department of Food Science and Technology, Federal University of Technology, Owerri, Nigeria, as well as Food Science laboratory at Rivers State University of Science and Technology, Port Harcourt, Nigeria. For emphasis, the anti-nutrients/phytochemicals determined include; oxalate, phytate, tannin, phenols, saponin, hydrogen cyanide [HCN], alkaloids, flavonoids, and trypsin inhibitors [TI], while the micronutrients include minerals and vitamins. Specifically, the minerals determined were magnesium $[\mathrm{Mg}]$, phosphorus $[\mathrm{P}]$, calcium $[\mathrm{Ca}]$, iron $[\mathrm{Fe}]$, zinc [Zn], potassium [K], sodium [Na], manganese [Mn], lead [Pb] and selenium [Se]. Specifically, also, the vitamins determined include thiamine [vitamin B1], riboflavin [vitamin B2], niacin [vitamin B3], beta carotene, ascorbic acid [vitamin C], and tocopherol [vitamin E]. Samples used in the analysis were chosen by simple random (aliquot) sampling from the population of the rubber seed meals (RRSM, BRSM, or FRSM). Independently and by analysing aliquot samples, duplicate determinations were carried out from the sample population (RRSM, BRSM, or FRSM) of rubber seed meals.

\section{Determination of anti-nutrient/phytochemical contents of rubber seed meals} a) Oxalate and phenol of rubber seed meal

The oxalate content of rubber seed meal was determined using the titration method described by Agbaire (2011), which involved mixing test sample $(1 \mathrm{~g})$ and $3 \mathrm{M} \mathrm{H}_{2} \mathrm{SO}_{4}$ on a magnetic stirrer for 1 hour, followed by filtration, then the filtrate titrated against $0.05 \mathrm{M}$

Peer) reviewing PDF | (2020:10:54065:2:0:NEW 22 Mar 2021) 
201

202

203

204

205

206

207

208

209

210

211

212

213

214

215

216

217

218

219

220

221

222

223

224

225

226

227

228

229

230

231

232

233

234

235

$\mathrm{KMnO}_{4}$ solution until a faint pink colour persisted for at least $30 \mathrm{~s}$. The oxalate content was then calculated by taking $1 \mathrm{ml}$ of $0.05 \mathrm{M} \mathrm{KMnO} 4$ as equivalent to $0.63 \mathrm{mg}$ oxalate.

The phenol content of rubber seed meal was determined using the colorimetric method described by Henriquez et al. (2010), which involved the reduction of FolinCiocalteau reagent by Phenolic compounds with a concomitant formation of a blue complex, followed by taking absorbance reading using UV-VIS Spectrophotometer Model 6305 (Bibby Scientific Ltd, UK) at a wavelength of 765nm. The measurement was compared to a standard curve prepared with Gallic Acid solution. The total phenolic content (TPC) was expressed as milligrams of Gallic Acid Equivalents (GAE) per gram of fresh weight.

Total phenolic content $=\frac{C \times V}{W}$

Eq. 1

Where $C=$ concentration of gallic acid calculated from the calibration curve $(\mathrm{mg} / \mathrm{ml})$ $\mathrm{V}=$ volume of extract $(\mathrm{ml})$

$\mathrm{W}=$ weight of the sample $(\mathrm{g})$

\section{b) saponin, flavonoid, and alkaloid of rubber seed meal}

Flavonoid and saponin content was determined using the method described by Okwulehie et al. (2017), while alkaloid content was determined using the method of Onwuka (2018). Whilst saponin employed double solvent extraction gravimetric method, alkaloid employed precipitation gravimetric method. Specifically, flavonoid, saponin, and alkaloid content expressed as $\mathrm{mg} / 100 \mathrm{~g}$ were calculated using the equation below;

Flavonoid/Saponin/Alkaloid $(\mathrm{mg} / 100 \mathrm{~g})=\frac{W 2-W 1}{\text { Weight of sample }} \times 100$

Eq. 2

Where; $\mathrm{W}_{1}=$ Weight of filter paper

$\mathrm{W}_{2}=$ Weight of filter paper plus flavonoid/saponin/alkaloid precipitate

\section{c) Tannin, HCN, phytate, and trypsin inhibitor of rubber seed meal}

The tannin, HCN, phytate, and trypsin inhibitor ( $\mathrm{TI})$ content of rubber seed meals were determined using UV-VIS Spectrophotometer Model 6305 (Bibby Scientific Ltd, UK) consistent with the method of Onwuka (2018). Further, the absorbance of tannin, $\mathrm{HCN}$, phytate, and trypsin inhibitor was read at a wavelength of $250 \mathrm{~nm}, 490 \mathrm{~nm}, 519$ $\mathrm{nm}$, and $410 \mathrm{~nm}$ respectively. The amount of measured tannin, $\mathrm{HCN}$, and phytate from rubber seed meals expressed in $\mathrm{mg} / 100 \mathrm{~g}$ was calculated using the equation below;

$$
\text { Tannin/Phytate/HCN }(\mathrm{mg} / 100 \mathrm{~g})=\frac{A u \times C \times V f \times 100}{W \times A s \times V a}
$$


250

251

252

253

254

As = Absorbance of standard solution

$\mathrm{C}=$ concentration of standard solution

$\mathrm{W}=$ Weight of sample used

$\mathrm{Vf}=$ Total volume of extract

$\mathrm{Va}=$ Volume of extract

On the other hand, one trypsin unit inhibited (TUI) is equal to an increase of 0.01 absorbance unit at $410 \mathrm{~nm}$. Therefore, trypsin inhibitor ( $\mathrm{TI}$ ) activity expressed as the number of trypsin units inhibited (TUI) per unit weight of the sample analysed was calculated using the equation below;

$$
\text { Trypsin inhibitor }(\mathrm{TUl} / \mathrm{mg})=\frac{A u \times 0.01 \times F}{A s}
$$

Where $A u=$ Absorbance of the test sample,

As = Absorbance of standard (uninhibited) sample

$\mathrm{F}=$ Experimental factors

Where experimental factor, $\mathrm{F}$ is expressed as

$$
\mathbf{F}=\frac{V f}{V a \times W}
$$

Where $\mathrm{Vf}=$ Total volume of extract

$\mathrm{Va}=$ Volume of extract analyzed

$\mathrm{W}=$ Weight of sample analyzed.

\section{Determination of micronutrients of rubber seed meals}

\section{a) Mineral contents of rubber seed meals}

The mineral contents (Mg, P, Ca, Fe, Zn, Mn, Pb, and Se) of rubber seed meal samples were determined, which entailed initial digestion in $\mathrm{HCl}$, and subsequently, the use of atomic absorption spectrophotometry (AAS) Model 200A (Buck Scientific Inc. USA), consistent with the AOAC method (AOAC, 2003). This involved background correction using an inserted lamp, internal flow of inert gas during charring, and properly regulated drying as liquid injections were micro-pipetted into the furnace. Analytical conditions were set as per the design manufacturer. On the other hand, other mineral contents ( $\mathrm{Na}$ and $\mathrm{K}$ ) of rubber seed meal samples were determined by initial calibration of Flame Photometer (FP) Model PFP-7 (Buck Scientific Inc., USA) using standard diluted element ( $\mathrm{Na} \& \mathrm{~K}$ ) solution to generate a standard curve, consistent with the method of AOAC (2003). Subsequently, the test sample was measured and each test element was extrapolated from the standard curve. When the analytical process ended, mineral content results were reported as the mean of three replicates.

\section{b ) Vitamin contents of rubber seed meals}


271

272

273

274

275

276

277

278

279

280

281

282

283

284

285

286

287

288

289

290

291

292

293

294

295

296

297

298

299

300

301

302

303

The vitamin B1, B2, and B3 content of rubber seed meals were determined using UV-VIS Spectrophotometer Model 6305 (Bibby Scientific Ltd, UK) consistent with the method of AOAC (2005). The absorbance of vitamin B1, B2, and B3 was read at a wavelength of $360 \mathrm{~nm}, 510 \mathrm{~nm}$, and $470 \mathrm{~nm}$ respectively. The amount of measured vitamin from rubber seed meals expressed in $\mathrm{mg} / 100 \mathrm{~g}$ was calculated using the equation below:

$$
\text { Vitamin B1/B2/B3 }(\mathrm{mg} / 100 \mathrm{~g})=\frac{100 \times A u \times C \times V t}{W \times A s \times V a}
$$

$$
\begin{aligned}
& \text { Where } \mathrm{W}=\text { weight of sample ash }(\mathrm{g}) \\
& \mathrm{Au}=\text { absorbance of the test sample } \\
& \mathrm{As}=\text { absorbance of standard thiamine solution } \\
& \mathrm{C}=\text { concentration of standard thiamine solution }(\mathrm{mg} / \mathrm{ml}) \\
& \mathrm{Vt}=\text { total extract volume }(\mathrm{ml}) \\
& \mathrm{Va}=\text { volume of extract analysed }(\mathrm{ml})
\end{aligned}
$$

The $\beta$-carotene content of rubber seed meals was determined using the method described by AOAC (2003), which involved test sample (5 g) homogenized in acetone solution, filtered (Whatman No. 1 filter paper, Merck KGaA, Darmstadt, Germany), and an aqueous solution containing $\beta$-carotene was extracted from the filtrate using petroleum spirit. The absorbance of the solution was read using UV-VIS Spectrophotometer Model 6305 (Bibby Scientific Ltd, UK) at a wavelength of $450 \mathrm{~nm}$. The amount of $\beta$-carotene expressed in $\mathrm{mg} / 100 \mathrm{~g}$ was calculated using the equation below;

$$
\text { Carotene content }(\mathrm{mg} / 100 \mathrm{~g})=\frac{A \times \operatorname{Volume}(\mathrm{ml}) \times 1000}{A c \times \operatorname{Sample} \operatorname{weight}(\mathrm{g})}
$$

Eq. 7

Where; $A=$ Absorbance

$10^{3}=$ dilution factor

$A_{c}=$ extinction coefficient of $1 \% \beta$-carotene solution at $450 \mathrm{~nm}$

The vitamin $c$ content of the rubber seed meal was determined according to the method described by Okwu and Ndu (2006), which involved test sample $(2 \mathrm{~g})$ homogenized in EDTA solution, filtered, and subsequently passing the filtrate through packed cotton wool containing activated charcoal to remove the colour. Potassium iodide and starch (indicator) solution were added to the filtrate and the mixture titrated against $0.01 \mathrm{M} \mathrm{CuSO}_{4}$ solution until an endpoint marked by black specks at the brink of the mixture is reached. The vitamin $\mathrm{C}$ content was given by the relationship that $1 \mathrm{ml}$ of $0.01 \mathrm{M} \mathrm{CuSO}_{4}$ equals $0.88 \mathrm{mg}$ vitamin $\mathrm{C}$ and therefore, calculated thus;

$$
\text { Vitamin } C(\mathrm{mg} / 100 \mathrm{~g})=\frac{100 \times V f \times 0.88 T}{W \times V a}
$$

Where $\mathrm{W}=$ weight of the sample $(\mathrm{g})$ 
$305 \mathrm{Vf}=$ total volume of extract $(\mathrm{ml})$

$306 \mathrm{Va}=$ volume of sample in extract $(\mathrm{ml})$

$307 \mathrm{~T}=$ titre value

308

309

310

311

312

313

314

315

316

317

318

319

320

321

322

323

324

325

326

327

328

329

330

331

332

333

334

335

336

337

338

339

340

341

342

343
The vitamin E content of rubber seed meal was determined using UV-VIS Spectrophotometer Model 6305 (Bibby Scientific Ltd, UK) consistent with the method of Achikanu et al. (2013), which involved macerating test sample $(1 \mathrm{~g})$ in $20 \mathrm{ml} \mathrm{n}$-hexane, followed by centrifuging (Yescom 800-1 Centrifugal machine, Model No: 35CEN001800-09, China) at $1500 \mathrm{rpm}$ for $10 \mathrm{~min}$. The centrifuged mixture was filtered, treated with $0.5 \mathrm{~N}$ alcoholic potassium hydroxide and ethanol, followed by evaporating filtrate ( 2 $\mathrm{ml}$ ) to dryness over a boiling water bath. Subsequently, the residue was mixed with ethanol, $0.2 \%$ ferric chloride, and $0.5 \% \alpha-\alpha^{1}$-dipyridyl, then the absorbance was taken at $520 \mathrm{~nm}$ against the blank (distilled water prepared with the procedures as the sample). The concentration of vitamin $E$ expressed in $\mathrm{mg} / 100 \mathrm{~g}$ was calculated below;

$$
\mathrm{C}_{\mathrm{x}}=\frac{A x \times C s}{A s}
$$

Eq. 9

\begin{abstract}
Where; $A x=$ Absorbance reading of the sample
As = Absorbance reading of the standard

$\mathrm{C}_{\mathrm{s}}=$ Concentration of the standard
\end{abstract}

\title{
Statistical analysis
}

The analysis of variance (ANOVA) assumptions considered homogeneity of variances and normality, which were based on Levene's, and Shapiro-Wilk tests respectively (Ofoedu et al., 2020). One-way analysis of variance (ANOVA) was applied to the data obtained from duplicate measurements of samples. Results of dependent variables were expressed as mean \pm standard deviation (SD). Fisher's least significant difference (LSD) was used to resolve mean differences. For all analyses, the probability level of statistical significance was set at $p<0.05$ ( $95 \%$ confidence interval). IBM SPSS software version 20 (IBM Corporation, New York, USA) was used to do the analysis.

\section{RESULTS}

\section{Variations in anti-nutrient/phytochemical contents}

Variations in anti-nutrient and phytochemical contents of rubber seed meal sample are shown in Table 1. Across the RRSM, BRSM, and FRSM samples, the antinutrient and phytochemical (namely: phytate, oxalate, tannin, saponin, $\mathrm{HCN}, \mathrm{TI}$, alkaloids, phenols, and flavonoids) differed significantly $(p<0.05)$. Largely, a significantly $(p<0.05)$ decreasing anti-nutrient and phytochemical composition trend seems obvious across the RRSM, BRSM, and FRSM samples. However, this appears not strictly so for the flavonoids, which in FRSM $(52.50 \mathrm{mgQE} / 100 \mathrm{~g})$ was significantly $(p<0.05)$ above that of BRSM (40.00 mgQE/100g). Across the RRSM, BRSM and FRSM samples, the antinutrient and phytochemical composition obtained diverse ranges, as shown in phytate (from 19.62 to $6.97 \mathrm{mg} / 100 \mathrm{~g}$ ), oxalate (from 13.26 to $3.36 \mathrm{mg} / 100 \mathrm{~g}$ ), tannin (from 8.98 to $0.92 \mathrm{mg} / 100 \mathrm{~g}$ ), saponin (from 4.91 to $1.60 \mathrm{mg} / 100 \mathrm{~g}$ ), $\mathrm{HCN}$ (from 12.41 to 1.97

Peer) reviewing PDF | (2020:10:54065:2:0:NEW 22 Mar 2021) 
$344 \mathrm{mg} / 100 \mathrm{~g}$ ), Tl (from 8.43 to $0.97 \mathrm{TiU} / \mathrm{mg}$ ), alkaloids (from 4.54 to $0.97 \mathrm{mg} / 100 \mathrm{~g}$ ), phenols

345 (from 2.77 to $0.50 \mathrm{mgGAE} / \mathrm{g}$ ), and flavonoids (from 60.00 to $40.00 \mathrm{mgQE} / 100 \mathrm{~g}$ )

346 contents. Also presented in Table 1 are some well-known referenced/published safety

347 limits, which will be used to discuss the results herein (Refer to discussion section),

348 specific to phytate $(<25 \mathrm{mg} / 100 \mathrm{~g})$, oxalate $(<10 \mathrm{mg} / 100 \mathrm{~g})$, tannin $(12 \mathrm{mg} / 100 \mathrm{~g})$, and

349 HCN (1 mg/100g) (Abdoulaye et al., 2011; FAO/WHO, 2011; Mark, 2020; Ndie \&

350 Okaka, 2018),. In general, the anti-nutrients/phytochemicals of processed (BRSM and

351 FRSM) were significantly lower $(p<0.05)$ compared to the raw/unprocessed (RRSM)

352 rubber seed meal samples. Overall, based on anti-nutrients/phytochemicals data, the

353 rubber seed meals would trend: RRSM>BRSM>FRSM, except for the flavonoids, which

354 would make it to trend: RRSM>FRSM>BRSM (Table 1).

\section{Variations in mineral contents}

Variations in mineral contents of rubber seed meal samples are shown in Table 2. Across the RRSM, BRSM, and FRSM samples, the mineral contents ( $\mathrm{Mg}, \mathrm{P}, \mathrm{Ca}, \mathrm{Fe}$, $\mathrm{Zn}, \mathrm{K}, \mathrm{Na}, \mathrm{Mn}, \mathrm{Pb}$, and $\mathrm{Se}$ ) differed significantly ( $\mathrm{p}<0.05)$. Specifically, FRSM obtained higher Mg (122.72 mg/100g), P (228.93 mg/100g), Ca (205.13 mg/100g), Fe (7.86 $\mathrm{mg} / 100 \mathrm{~g}), \mathrm{Zn}(1.56 \mathrm{mg} / 100 \mathrm{~g}), \mathrm{K}(800.16 \mathrm{mg} / 100 \mathrm{~g})$ and $\mathrm{Na}(10.52 \mathrm{mg} / 100 \mathrm{~g})$ compared to those of RRSM and BRSM. Peaks of Mn $(0.41 \mathrm{mg} / 100 \mathrm{~g}), \mathrm{Pb}(0.12 \mathrm{mg} / 100 \mathrm{~g})$ and $\mathrm{Se}$ $(0.03 \mathrm{mg} / 100 \mathrm{~g})$ were found at RRSM. Additionally, the mineral contents of BRSM recorded the least values except for selenium $(0.02 \mathrm{mg} / 100 \mathrm{~g})$, which was above that of FRSM $(0.00 \mathrm{mg} / 100 \mathrm{~g})$. Across the RRSM, BRSM and FRSM samples, the mineral composition obtained diverse ranges, as shown in $\mathrm{Mg}$ (from 112.15 to $122.72 \mathrm{mg} / 100 \mathrm{~g}$ ), $\mathrm{P}$ (from 220.72 to $228.93 \mathrm{mg} / 100 \mathrm{~g}$ ), Ca (from 193.57 to $205.13 \mathrm{mg} / 100 \mathrm{~g}$ ), $\mathrm{Fe}$ (from 4.95 to $7.86 \mathrm{mg} / 100 \mathrm{~g}$ ), Zn (from 0.99 to $1.56 \mathrm{mg} / 100 \mathrm{~g}$ ), $\mathrm{K}$ (from 778.10 to $800.16 \mathrm{mg} / 100 \mathrm{~g}$ ), $\mathrm{Na}$ (from 9.84 to $10.52 \mathrm{mg} / 100 \mathrm{~g}$ ), $\mathrm{Mn}$ (from 0.35 to $0.41 \mathrm{mg} / 100 \mathrm{~g}$ ), $\mathrm{Pb}$ (from 0,07 to $0.12 \mathrm{mg} / 100 \mathrm{~g}$ ), and Se (from 0.00 to $0.03 \mathrm{mg} / 100 \mathrm{~g}$ ), No Nickel (Ni) was detected. Also presented in Table 2 are some well-known referenced/published safety limits, which will be used to discuss the results herein (Refer to discussion section), specific to $\mathrm{Mg}$ (220$260 \mathrm{mg} / 100 \mathrm{~g}), \mathrm{P}(700 \mathrm{mg} / 100 \mathrm{~g}), \mathrm{Ca}(1000 \mathrm{mg} / 100 \mathrm{~g}), \mathrm{Fe}(8-18 \mathrm{mg} / 100 \mathrm{~g}), \mathrm{Zn}(8-11$ $\mathrm{mg} / 100 \mathrm{~g}), \mathrm{K}(3500 \mathrm{mg} / 100 \mathrm{~g}), \mathrm{Na}(<2000 \mathrm{mg} / 100 \mathrm{~g}), \mathrm{Mn}(1.8-2.3 \mathrm{mg} / 100 \mathrm{~g})$, and Se (55 rg) (FAO/WHO, 2001; Institute of Medicine, 2000; NIH, 2020; WHO, 2012a \& b). Overall, based on quantities, the trend of mineral content across samples would follow: FSRM > RRSM > BRSM, except for selenium, which would make it to trend:

RRSM>BRSM>FRSM (Table 2). The rubber seed meal can be considered as fortified with mineral elements ( $\mathrm{Mg}, \mathrm{P}, \mathrm{Ca}, \mathrm{Fe}, \mathrm{Zn}, \mathrm{K}, \mathrm{Na}, \mathrm{Mn}, \mathrm{Pb}$, and $\mathrm{Se}$ ).

\section{Variations in vitamin contents}

Variations in vitamin contents of rubber seed meal samples are shown in Table 3. Across the RRSM, BRSM, and FRSM samples, the vitamin contents (vitamin B1, B2, $B 3, C, E$, and $\beta$-carotene) differed significantly $(p<0.05)$. Additionally, the vitamin contents obtained diverse ranges across the RRSM, BRSM, and FRSM samples, as shown in vitamin B1 (from 0.21 to $0.30 \mathrm{mg} / 100 \mathrm{~g}$ ), vitamin B2 (from 0.31 to 0.52 $\mathrm{mg} / 100 \mathrm{~g}$ ), vitamin B3 (from 0.51 to $0.77 \mathrm{mg} / 100 \mathrm{~g}$ ), vitamin C (from 10.03 to 29.09 $\mathrm{mg} / 100 \mathrm{~g}$ ), vitamin $E$ (from 5.92 to $8.90 \mathrm{mg} / 100 \mathrm{~g}$ ), and $\beta$-carotene (from 2.09 to 3.77 $\mathrm{mg} / 100 \mathrm{~g}$ ), Considering the vitamin content data, those of RRSM obtained the highest 
388

389

390

391

392

393

394

395

396

397

398

399

400

401

402

403

404

405

406

407

408

409

410

411

412

413

414

415

416

417

418

419

420

421

422

423

424

425

426

427

428

429

430

431

values whereas those of BRSM obtained the least values. Additionally, the vitamin content values in FRSM were significantly higher $(p<0.05)$ compared to those of BRSM. Overall, based on quantities, the trend of vitamin content across samples would follow: RRSM > FSRM > BRSM. Also presented in Table 3 are some well-known referenced/published safety limits, which will be used to discuss the results herein (Refer to discussion section), specific to vitamin B1 (1.1 - 1.2 mg/100g), B2 (1.1 - 1.3 $\mathrm{mg} / 100 \mathrm{~g})$, B3 (14 - $16 \mathrm{mg} / 100 \mathrm{~g}), \mathrm{C}$ (60 mg/100g), E (15 mg/100g), and $\beta$-carotene (0.7 $0.9 \mathrm{mg} / 100 \mathrm{~g}$ ) (Finglas, 2000; Kirkland \& Meyer-Ficca, 2016; Kubala, 2018; Institute of Medicine, 2000; NIH 2020).

\section{DISCUSSION}

The phytate range of rubber seed meal (from 6.97 to $19.62 \mathrm{mg} / 100 \mathrm{~g}$ ) (Table 1), was below those Popova and Mihaylova (2019) reported for legume grains (386 to 714 $\mathrm{mg} / 100 \mathrm{~g})$, nearer to those Abdulhamid et al, (2014) reported for Egusi (3.09 mg/100g), and falls below $<25 \mathrm{mg} / 100 \mathrm{~g}$ safety threshold applied to edible grains (Abdoulaye et al., 2011). As an anti-nutritive agent, phytic acid blocks absorption and limits the bioavailability of such minerals as Fe, Zn, and $\mathrm{Ca}$ (Urbano et al., 2000). Oxalates, on the other hand, bind to minerals like $\mathrm{Ca}$, Fe, and $\mathrm{Mg}$ to form insoluble compounds, which brings some concerns given that calcium oxalate has been implicated in kidney stones, and render it unavailable for absorption (Spritzler, 2017). The oxalate range of rubber seed meal (from 3.36 to $13.26 \mathrm{mg} / 100 \mathrm{~g}$ ) (Refer to Table 1) fell below those Mark (2020) reported for (boiled) soybeans $(52 \mathrm{mg} / 100 \mathrm{~g})$ but compares well with those of Mung beans $(8 \mathrm{mg} / 100 \mathrm{~g})$. Mark (2020) considered foods containing $>10 \mathrm{mg}$ oxalate as high-oxalate food, consistent with the classification of the American Dietetic Association(ADA). Based on this argument, we opine that the processed rubber seed meal herein is low in oxalates.

The tannin range of rubber seed meal (from 0.92 to $8.98 \mathrm{mg} / 100 \mathrm{~g}$ ) (Refer to Table 1) was below those Popova and Mihaylova (2019) reported for legumes (soybeans, peanuts, and beans) $(1.8$ - $18 \mathrm{mg} / 100 \mathrm{~g})$ and compares well with Egusi (6.19 $\mathrm{mg} / 100 \mathrm{~g}$ ) (Abbdulhamid et al., 2014). The stipulated maximum limit of tannin in food is $12 \mathrm{mg} / 100 \mathrm{~g}$ (Ndie and Okaka, 2018). Above this, the protein absorption can be compromised, and if this were to happen in a consumer, the intestinal wall could be damaged. Based on this argument, the tannin of rubber seed meal herein can be considered below the tannin safety limits. The saponin range of rubber seed meal (from 1.60 to $4.91 \mathrm{mg} / 100 \mathrm{~g}$ ) (Refer to Table 1) was below those Banaskiewicz (2011) reported for soybean meal (60 mg/100g) and those Russo and Reggiani (2016) reported for linseed meal $(17 \mathrm{mg} / 100 \mathrm{~g})$. Saponins, despite their haemolytic activity and bitter taste which limits their palatability, still show cholesterol-lowering and anticancer properties as health benefits and remain commercially significant given their applicability across food and pharmaceutical industries (Guclu-Ustundag \& Mazza, 2007).

The HCN range of rubber seed meal (from 1.97 to $12.41 \mathrm{mg} / 100 \mathrm{~g}$ ) (Refer to Table 1) fell below those Obiakor-Okeke (2014) reported for raw lima beans flour (38.38$43.55 \mathrm{mg} / 100 \mathrm{~g}$ ), those Khan et al. (2010) reported for linseed $(31.05 \mathrm{mg} / 100 \mathrm{~g})$, and those Farr et al., (2019) reported for roasted $(14.30 \mathrm{mg} / 100 \mathrm{~g})$ rubber seed meal. Results herein showed that FRSM recorded the highest percentage reduction in $\mathrm{HCN}$

Peer) reviewing PDF | (2020:10:54065:2:0:NEW 22 Mar 2021) 
432 (84.13\%) while BRSM had the least (62.05\%) percentage reduction in HCN. The 433 reduced $\mathrm{HCN}$ in rubber seed could be due to inactivation of glycosidase, leaching, and 434 vaporization of $\mathrm{HCN}$ after it is formed from cyanogenic glycosides hydrolysis and/or the 435 destruction of the cyanogenic glycoside compounds (Feng, Shen \& Chavez, 2003). 436 Probably, the combination of boiling and fermentation in FRSM helped to reduce the $\mathrm{HCN}$, which agrees with the report of Daulay et al., (2014). Differences in nature (flour, liquid, solids, gruel, coarse, etc.) of associated foods can also result in HCN variations. Moreover, the safety limit of cyanide differs across foods. For instance, maximum levels of HCN in cassava flour $(1 \mathrm{mg} / 100 \mathrm{~g})$, garri $(0.2 \mathrm{mg} / 100 \mathrm{~g})$, nougat and marzipan (5 $\mathrm{mg} / 100 \mathrm{~g})$, alcoholic beverages $(3.5 \mathrm{mg} / 100 \mathrm{~g})$, and canned stone fruits $(0.5 \mathrm{mg} / 100 \mathrm{~g})$ have already been established by the Codex Alimentarius Commission (FAO/WHO, 2011; EFSA, 2016; Schrenk et al., 2019). Interestingly, there appears to be no regulation that has stipulated the cyanide levels in foods (EFSA, 2016). HCN variations found in the processed rubber seed meals herein might suggest that the processing methods did not sufficiently detoxify/eliminate the cyanogenic contents. Sharma, Saha, and Saha (2014) equally emphasised that there is a great need to develop economical ways of detoxifying cyanogenic-containing food products, especially removing up to $85 \%$ of the toxicant $(\mathrm{HCN})$. However, considering that the lethal dose of cyanide is 0.5 to $3.5 \mathrm{mg} / \mathrm{kg}$ body weight (bw) (EFSA, 2016), a $70 \mathrm{~kg}$ of weight adult, for example, would have to consume about $35 \mathrm{mg}$ of $\mathrm{HCN}$ to become affected, which would be based on the minimum lethal dose of cyanide of $0.5 \mathrm{mg} / \mathrm{kg} \mathrm{bw}$, and such would equal to $1776 \mathrm{~g}$ of FRSM and $743 \mathrm{~g}$ of BRSM, and this is most unlikely to happen for any daily consumption. In the view to reduce the HCN content of FRSM below toxic level, increased hours of boiling and fermentation of the rubber seed should strongly be recommended for it to be used as food and feed.

The $\mathrm{TI}$ activity range of processed rubber seed meal $(0.97$ to $8.43 \mathrm{TiU} / \mathrm{mg})$ (Refer to Table 1) fell below those Yalcin and Basman (2015) reported for soybeans (94.1 $\mathrm{TiU} / \mathrm{mg}$ ) but competes well with those Embaby (2010) reported for peanut (5.60 $\mathrm{TiU} / \mathrm{mg})$. The $\mathrm{Tl}$ activity decreased significantly $(p<0.05)$ in the processed rubber seed meal (8.43 to $0.97 \mathrm{TiU} / \mathrm{mg}$ ) (Table 1), recording a percentage reduction of $62.04 \%$ for BRSM and $88.50 \%$ for FRSM. This appears not consistent with the report of Udo et al., (2016) and Farr et al., (2019), who demonstrated heat processing to deliver up to $100 \%$ reduction in $\mathrm{Tl}$ activity. Variations in $\mathrm{Tl}$ activity of the rubber seed meal herein probably arose due to varietal differences (of product), harvest period, and differences in processing methods/treatments. Besides, we could not find any recorded safety limits of $\mathrm{TI}$ activity in foods. Potentially, such conventional processing like fermentation and heat treatments could deactivate the TI activity.

Alkaloids are important chemical compounds, with strong biological effects on humans, even at very small doses (Kurek, 2019). Herein, the alkaloid content range of processed rubber seed meal $(0.97$ to $4.54 \mathrm{mg} / 100 \mathrm{~g})$ (Table 1$)$ compares favourably with those Okwu and Orji (2007) reported for soy and cowpea seeds $(1.49-1.64 \mathrm{mg} / 100 \mathrm{~g})$. Known for their bitter taste, alkaloids could perform some anti-inflammatory and analgesic functions, and serve as a local anaesthetic for pain relief, supplemented by their antimicrobial and antifungal properties (Kurek, 2019). On the other hand, the total phenolic content range of processed rubber seed meals (0.50 - $2.77 \mathrm{mgGAE} / \mathrm{g}$ ) (Refer 
477 to Table 1) compares favourably with that Mujic et al., (2011) reported for soybean (0.87 478 to $2.16 \mathrm{mgGAE} / \mathrm{g}$ ). Phenols are important in enhancing the nutritional value in foods, 479 acting as antioxidants (that can prevent cellular damage due to free radical oxidation

480

481

482

483

484

485

486

487

488

489

490

491

492

493

494

495

496

497

498

499

500

501

502

503

504

505

506

507

508

509

510

511

512

513

514

515

516

517

518

519 reactions) as well as anti-inflammatory agents (Reis-Giada, 2013). The flavonoids content of RRSM (60.00 mgQE/100g), BRSM (40.00 mgQE/100g), and FRSM (52.50 $\mathrm{mgQE} / 100 \mathrm{~g}$ ) (Table 1) compares favourably with those of soybean $(51 \mathrm{mg} / 100 \mathrm{~g})$ (Josipovic et al., 2016). Unlike the trend reported in the other phytochemicals of the current study, the FRSM obtained about a $30 \%$ increase in flavonoids over the BRSM (Refer to Table 1), and given such (increases in flavonoids), the fermentation process might improve the antioxidant activity (Hur et al., 2014). A significant increase in flavonoids with okra fermentation has been reported elsewhere (Adetuyi and Ibrahim, 2014). The undesirable bitter taste of flavonoids may limit its use as food bioactive, despite being associated with a broad spectrum of health-promoting effects, for example, anti-oxidative, anti-inflammatory, anti-mutagenic, and anti-carcinogenic effects (Panche et al., 2016).

Indeed, the anti-nutrient composition of food products could be impacted by processing methods (Udo et al., 2016). Comparably, the reduction in anti-nutrient levels of grains/legumes could arise from conventional processing methods, like soaking, dehulling, boiling, pressure cooking, germination, and fermentation (Patterson et al., $2016)$. Herein, the boiling might have significantly $(p<0.05)$ reduced the antinutrient/phytochemical contents in BRSM, specifically between $43-75 \%$. In like manner, the combined action of boiling and fermentation process might have significantly $(p<0.05)$ reduced the anti-nutrient/phytochemicals in FRSM, specifically between $64-89 \%$. The combined effects of boiling and fermentation, in varying degrees, might be contributing to some of the reductions in antinutrients/phytochemicals in these rubber seed meals, which could happen as the enzyme gets released by microbial-led fermentation (Sokrab, Ahmed \& Babiker, 2014). Boiling, as a processing method, would, not only hydrate the product matrix but also, induce the leaching out of water-soluble anti-nutrients/phytochemicals (Nwosu et al., 2013).

Feasibly, the processing methods might have influenced the mineral losses/retention in the processed rubber seed meals, either through leaching process during boiling, from the samples into the processing water (Gokoglu et al., 2004; Ihediohanma et al., 2014; Osuji, Ofoedu \& Ojukwu, 2019), or (solid-state) fermentation, which markedly improves the nutritive values of food (Ibeabuchi et al., 2014), or reductions in the overall anti-nutrients that determines the (actual) mineral contents of seed meal samples (Kumar et al., 2010). The Ca range (193.57-205.13 mg/100g) obtained herein (Refer to Table 2) fell below the $1000 \mathrm{mg} /$ day recommended dietary allowance (RDA) of FAO/WHO (2001). Besides, Ca occurring in (rubber seed meal) products might be facilitating both absorption and bioavailability of minerals like $\mathrm{Mg}$ and Zn (Agbaje, Hassan, Arifin, and Rahman, 2014; Ofoedu et al., 2020). Additionally, muscle function, vascular contraction/vasodilation, nerve transmission, and hormonal secretions within the human body are associated with Ca (Institute of Medicine, 2010). 
As a cofactor of many enzyme systems, Mg can regulate diverse biochemical reactions as well as physiological activities (Agbaje, Hassan, Arifin, and Rahman, 2014; Rude, 2014). Herein, the range of $\mathrm{Mg}$ of processed rubber seed mea I(112.15 - 122.72 $\mathrm{mg} / 100 \mathrm{~g}$ ) (Refer to Table 2) fell below the WHO dietary recommended daily intake (RDI) (FAO/WHO, 2001), which makes it a fair source (of Mg). In like manner, the range of $\mathrm{Zn}$ in the processed rubber seed meals $(0.99$ to $1.56 \mathrm{mg} / 100 \mathrm{~g}$ ) (Table 2) fell below the RDI for males (11 mg/day) and females ( $8 \mathrm{mg} /$ day), which is required for DNA synthesis/cell division, enzyme-catalytic activities, immune function, protein synthesis, and wound healing (Institute of Medicine, 2001). The $P$ range in processed rubber seed meals (220.72 to $228.93 \mathrm{mg} / 100 \mathrm{~g}$ ) (Refer to Table 2), seemed about one-third of the WHO dietary RDI of $700 \mathrm{mg} /$ day $(\mathrm{WHO}, 2012 \mathrm{a})$. The $\mathrm{P}$ remains among the human body's essential energy source (ATP) and is very needed in bones, teeth, and cells (Heaney, 2012).

As an essential part of haemoglobin and myoglobin, Fe enhances physical growth, neurological development, cellular function, and hormonal synthesis, and facilitates healthy connective tissue and muscle metabolism (Wessling-Resnick, 2014). Herein, the Fe range in the processed rubber seed meals $(4.95$ to $7.86 \mathrm{mg} / 100 \mathrm{~g}$ ) (Table 2) compares favourably with RDI for men ( $8 \mathrm{mg} /$ day) and women (18mg/day) (WHO, $2012 b)$. Additionally, the $\mathrm{K}$ range in the processed rubber seed meal (778.10 to 800.16 $\mathrm{mg} / 100 \mathrm{~g}$ ) (Refer to Table 2), although compared favourably with $813.10 \mathrm{mg} / 100 \mathrm{~g}$ of linseed (Sayer, 2018), appears lower than the RDI recommended for adults (3500 $\mathrm{mg} /$ day) (WHO, 2012b). In the human body, K plays a significant role in muscle contractions, heart function, and managing water balance (Pohl et al., 2013). Herein, the $\mathrm{Na}$ range in the processed rubber seed meal $(9.84$ to $10.52 \mathrm{mg} / 100 \mathrm{~g})$ (Table 2) appears lower than those VanEys et al. (2004) reported for soybeans $(29 \mathrm{mg} / 100 \mathrm{~g})$ and Sayer (2018) reported for linseed (30 mg/100g). Reduced Na intake of less than 2000 $\mathrm{mg} / \mathrm{day}$, as recommended by WHO, would reduce the risks of high blood pressure, cardiovascular disease, stroke, and coronary heart diseases (WHO, 2012). The $\mathrm{Na}$ in the processed rubber seed meal, herein, is quite low, compared to the WHO recommended limit of $2000 \mathrm{mg} /$ day (WHO, 2012).

More so, Se is an important trace mineral essential for the proper functioning of the human body, given its significant role in metabolism and thyroid function, to protect the body from damage caused by oxidative stress (Kubala, 2019). Herein, the Se range ( 0.02 to $0.03 \mathrm{mg} / 100 \mathrm{~g}$ ) (Refer to Table 2 ) in rubber seed meal resembled values of other oil seeds such as peanut $(0.0313 \mathrm{mg} / 100 \mathrm{~g})$, corn $(0.0332 \mathrm{mg} / 100 \mathrm{~g})$, sunflower $(0.0225 \mathrm{mg} / 100 \mathrm{~g})$ and soybean $(0.0458 \mathrm{mg} / 100 \mathrm{~g})$ (Dugu et al, 2003). As a trace mineral required by the body in small amount, the amount of Se in the rubber seed meal compared favourably with the RDA of 0.0055 to $0.0070 \mathrm{mg}$ per day (that is, 0.0055 $\mathrm{mg} / \mathrm{day}$ for adult men and women, $0.0065 \mathrm{mg} /$ day for lactating women and 0.0070 $\mathrm{mg} /$ day for pregnant women (Winther et al., 2017; Anon. 2021; IM, 2020). Processing methods, however, reduced the amount of Se in the rubber seed meal, as the BRSM recorded $0.02 \mathrm{mg} / 100 \mathrm{~g}$, whereas it (the Se) might have been lost in the FRSM $(0.00$ $\mathrm{mg} / 100 \mathrm{~g}$ ). Utilising boiling method to process the rubber seeds, despite the latter's specific antioxidant property, appears to be efficient in retaining some of the Se in the rubber seed meal. 
565

566

567

568

569

570

571

572

573

574

575

576

577

578

579

580

581

582

583

584

585

586

587

588

589

590

591

592

593

594

595

596

597

598

599

600

601

602

603

604

605

606

607

608

Vitamins (B1, B2, B3, C, E, and $\beta$-carotene) across the RRSM, BRSM, and FRSM samples (Refer to Table 3 ) resemble those reported in soybean, sunflower, rapeseed, cotton, and groundnut (Muhammad et al., 2013). Ranges of vitamins B1 (0.21 to $0.30 \mathrm{mg} / 100 \mathrm{~g}), \mathrm{B} 2(0.31$ to $0.52 \mathrm{mg} / 100 \mathrm{~g})$, and B3 $(0.51$ to $0.77 \mathrm{mg} / 100 \mathrm{~g})$ across the rubber seed meals, (Table 3 ) fell below the RDA standards of vitamin B1, B2, and B3 for male $(1.2 \mathrm{mg} /$ day, $1.3 \mathrm{mg} /$ day, and $16 \mathrm{mg} /$ day $)$ and female $(1.1 \mathrm{mg} / \mathrm{day}, 1.1$ $\mathrm{mg} /$ day, and $14 \mathrm{mg} /$ day) respectively (WHO, 2012), which makes them a fair source of the B vitamins. Typically, the B vitamins help the body's cells to process the nutrients (carbohydrate, protein, and fat) into energy, as well as ensure normal nervous/psychological functions (Shachdev \& Shah, 2020; Bradford, 2015). The $\beta$ carotene is a precursor of vitamin $A$ (retinol) since the human body converts $\beta$-carotene to retinol (Newman, 2017). The rubber seed meals had $\beta$-carotene (Provitamin A) values of $3.77 \mathrm{mg} / 100 \mathrm{~g}$ for RRSM, $2.09 \mathrm{mg} / 100 \mathrm{~g}$ for BRSM, and $3.22 \mathrm{mg} / 100 \mathrm{~g}$ for FRSM (Refer to Table 3). Therefore, to convert the $\beta$-carotene into its retinol equivalent requires that $0.006 \mathrm{mg} \beta$-carotene would equal $0.001 \mathrm{mg}$ retinol (Scott \& Rodriquez, 2000; EFSA, 2015). Therefore, the retinol of the RRSM (3.77 mg/100g), BRSM (2.09 $\mathrm{mg} / 100 \mathrm{~g})$, and FRSM $(3.22 \mathrm{mg} / 100 \mathrm{~g})$ would equal $0.6283 \mathrm{mg} / 100 \mathrm{~g}, 0.3483 \mathrm{mg} / 100 \mathrm{~g}$, and $0.5367 \mathrm{mg} / 100 \mathrm{~g}$, respectively. Based on the recommended dietary allowance (RDA) of vitamin A for adult men $(0.9 \mathrm{mg})$ and women $(0.7 \mathrm{mg})$ (Kubala, 2018), the rubber seed meal herein suggests to be a good source of provitamin A. Additionally, $\beta$ carotene remains an antioxidant that protects the body from free radicals (Newman, 2017).

Given the range of vitamin C (10.03 to $29.09 \mathrm{mg} / 100 \mathrm{~g}$ ) and vitamin E (5.92 to $8.90 \mathrm{mg} / 100 \mathrm{~g}$ ), the BRSM obtained the least (vitamins $C$ and E) values (Refer to Table 3). The daily recommended dietary allowance is $60 \mathrm{mg}$ for vitamin $C$ (Institute of Medicine, 2000) and 15mg for vitamin $\mathrm{E}(\mathrm{NIH}, 2020)$. Thus, the rubber seed meal is a fair source of vitamin E, but a poor source of vitamin C. Nonetheless, processing (boiling and fermentation) methods might have affected the vitamins $C$ and $E$ herein. Vitamin losses have been associated with the leaching of soluble components (Osuji, Ofoedu \& Ojukwu, 2019; Ihediohanma et al., 2014) into the processing water. Though (rubber seed meal) products from FRSM were subjected to boiling prior to fermentation, Eyarkai, Chandrasekar, and Karthikeyan (2017) reported that (solid-state) fermentation could improve the nutritive value (vitamins) of the food product. The significantly higher $(p<0.05)$ vitamin $C$ and $E$ in FRSM, compared to BRSM (Table 3), could be that microbial action potentially enhanced these specific vitamins ( $C$ and $E$ ).

\subsection{CONCLUSIONS}

The changes in anti-nutrient, phytochemical, and micronutrient contents of different processed rubber seed meals were successfully investigated. For emphasis, the rubber seeds underwent processing, which brought about three seed meal flour groups, i.e., raw, boiled, and fermented rubber seed meals. Processing methods were shown to markedly influence the studied anti-nutrient/phytochemical and micronutrient (vitamins and minerals) contents of the rubber seed meals. Specifically, the combined action of boiling and fermentation processes effectively brought about some noticeable reduction in anti-nutrients. Despite that FRSM obtained significantly higher mineral

Peer) reviewing PDF | (2020:10:54065:2:0:NEW 22 Mar 2021) 
609 content compared to the other groups (RRSM and BRSM), it also obtained the least 610 phytochemical/anti-nutrient composition, except for flavonoid. The FRSM obtained a 611 higher vitamin content, after RRSM. Importantly, the processing methods herein have 612 not yet succeeded in removing $\mathrm{HCN}$ in the (processed) rubber seed meals, but can be

613 seen to be heading toward the right direction.

614 Given that the rubber seed is a source of micronutrients in an appreciable amount, fermentation seems to have enriched the nutritive value of its seed meal. The combined action of boiling and fermentation should be recommended for the proper 617 utilisation of rubber seed as food/feed and in the production of edible oil. It should also 618 be recommended that processed rubber seed meals be used in proportionate amounts during food product formulation sto enhance the nutrient content of the product as well as mask the effect of such anti-nutrients like HCN and TI. Further, the rubber seeds should be exposed to increased (high) temperature treatment, such as prolonged boiling before fermentation, which can help enhance the detoxification of toxicants, that may be carried over into the processed seed meal. Subsequently, this research lays the foundation for future studies towards the determination of the toxicity levels, and nutrient retention of rubber seeds processed by either boiling and fermentation, or non-thermal processing techniques, like ultrasound, cold plasma, pulsed electric field, high-pressure processing, and pulsed light.

\title{
ACKNOWLEDGEMENTS
}

CORO and MK appreciate funding (POWER+Incentive) of Wroclaw University of Environmental and Life Sciences, Poland.

631

632

633

634

635

636

637

638

639

640

641

642

643

644

645

646

647

648

\section{CONFLICT OF INTEREST STATEMENT}

\author{
Charles Odilichukwu R. Okpala is an Academic Editor of PeerJ.
}

\section{FUNDING}

Publication financed by the project UPWR 2.0: international and interdisciplinary programme of development of Wrocław University of Environmental and Life Sciences, co-financed by the European Social Fund under the Operational Program Knowledge Education Development, under contract No. POWR.03.05.00-00-Z062/18 of June 4, 2019.

\section{AUTHOR CONTRIBUTIONS}

CAM, IOA, and CJI conceived/conducted the study and prepared the initial manuscript draft. CEO, CORO, IS, and MK revised the manuscript draft and strengthened the scientific interpretation. All authors contributed to the intellectual content and confirmed the final submitted version.

\section{REFERENCES}

Abdoulaye, C., Brouk, K. and Jie, C. (2011). Phytic acid in cereal grains: structure, healthy or harmful ways to reduce phytic acid in cereal grains and their effects on nutritional quality. American Journal of Plant Nutrition and Fertilization Technology, 1(1): 1-22. 
649

650

651

652

653

654

655

656

657

658

659

660

661

662

663

664

665

666

667

668

669

670

671

672

673

674

675

676

677

678

679

680

681

682

683

684

685

686

Abdulhamid, A., Ibrahim, I. And Warra, A. A. (2014). Estimation of some antinutritional factors in oil-free cake of egusi (Citrullus colocynthis L.). Journal of Food and Dairy Technology, 2(1): 9-11.

Achikanu, C. C., Eze-steven, P., Ude, C. M. and Ugwokolie, O. C. (2013). Determination of the vitamin and mineral composition of common leafy vegetables in southeastern Nigeria. International Journal of Current Microbiology and Applied Sciences, 2(11): 347-353.

Adetuyi, F. O. and Ibrahim, T. A. (2014). Effect of fermentation time on the Phenolic, flavonoid, and vitamin $\mathrm{C}$ contents and antioxidant activities of Okra (Abelmoschus esculentus) seeds. Nigerian Food Journal, 32(2):128-137.

Agbai, C.M., Olawuni, I.A., Azeke, A.E., Nwokenkwo, E.C. \& Alagbaoso, S.O. (2020). Evaluation of proximate and functional properties of rubber (Hevea brasiliensis) seed meals. African Journal of Food Science 14(11): 407-413.

Agbaire, P. O. (2011). Nutritional and antinutritional levels of some local vegetables (Vernomia anydalira, Manihot esculenta, Teriferia occidentalis, Talinium triangulare, Amaranthus spinosus) from Delta state, Nigeria. Journal of Applied Sciences and Environmental Management, 15(4): 625-628.

Agbaje, R., Hassan, C.Z., Arifin, N., and Rahman, A.A. (2014). Senosry preference and mineral contents of cereal bars made from glutinous rice flakes and Sunnah foods. IOSR Journal of Environmental Science and Toxicology Food Technology 8(12): 26-31.

Aguihe, P. C., Kehinde, A. S., Ospina-Rojas, C. I. and Murakami, A. E. (2017). Evaluation of processing methods of rubber (Hevea brasiliensis) seed meal for use as a feed ingredient for broiler chickens. Journal of Poultry Research, 14(1):139-146.

Akinmutimi, A.H., (2004). Evaluation of Sword Bean (Canavalia gladiata) as an Alternative Feed Resource for Broiler Chicken Ph.D. Dissertation. Michael Okpara University of Agriculture, Umudike, Nigeria, p. 137.

Anonymous (2021). Selenium - The Nutrition Source. Harvard T.H. Chan School of Public Health. https://www.hsph.harvard.edu/nutritionsource/selenium/ Retrieved February 16, 2021.

AOAC. (2003). Official method of analysis. (17 th edition). Association of Analytical Chemists International, Arlington, Virginia, USA.

AOAC. (2005). Official method of analysis. (18 $18^{\text {th }}$ edition). Association of Analytical Chemists International, Gaithersburg, Maryland, USA.

Atasie, V. N., Akinhanmi, T. F. and Ojiodu, C. C. (2009). Proximate analysis and physic chemical properties of groundnut (Arachis hypogaca L.). Pakistan Journal of Nutrition, 8(2):194-197. 
687

688

689

690

691

692

693

694

695

696

697

698

699

700

701

702

703

704

705

706

707

708

709

710

711

712

713

714

715

716

717

718

719

720

721

722

723

Banaskiewicz, T. (2011). Nutritional value of soybean meal. IntechOpen Open access peer-reviewed chapter. Retrieved from https://www.intechopen.com/books/soybean-and-nutrition/nutritional-value-ofsoybean-meal. Accessed May 15th, 2020.

Basher, M. A. and Jumat, S. (2010). Toxicity study of Malaysian Rubber (Hevea brasiliensis) seed oil as rats and shrimps test. Asian Journal of Biochemistry, 5:33-39.

Bigliardi, B. \& Galanakis, C. (2020). Innovation management and sustainability in the food industry: concepts and models. In C. Galanakis (Ed.), The Interaction of Food Industry and Environment (pp. 315-340). London, Uk: Academic press.

Bolarinwa, I.F., Oke, M.O., Olaniyan, S.A. \& Ajala, A.S. (2016). A Review of Cyanogenic Glycosides in Edible Plants. In: Toxicology - New Aspects to This Scientific Conundrum, Sonia Soloneski and Marcelo L. Larramendy, (eds). IntechOpen, DOI: 10.5772/64886. Available from: https://www.intechopen.com/books/toxicology-new-aspects-to-this-scientificconundrum/a-review-of-cyanogenic-glycosides-in-edible-plants

Bradford, A. (2015). Vitamin B2 (Riboflavin): Sources, Benefits and Dosage. Available: http://www.livescience.com Accessed on October 2, 2020.

Csapo, J. and Albert, C. (2018). Methods and procedures for reducing soy trypsin inhibitor activity by means of heat treatment combined with chemical methods. Acta Universitatis Sapientiae Alimentaria, 11:58-80.

Daulay, S. S., Adelina, S. and Suharman, I. (2014). Detoxification of hydrogen cyanide acid (HCN) from rubber seed (Hevea brasiliensis Mull, Arg) through some physical treatment as fish feed ingredients. Journal Online Mahasiswa 1(2): 1 9.

Drago, S.R. (2017). Minerals. In: Nutraceuticals and functional food component. Effects of Innovative processing techniques. Charis M. Galanakis (eds.). Academic Press, Pp. 129-157.

Dugu, G., Pera, L. L., Pollicino, D. and Saitta, M. (2003). Determination of selenium content in different types of seed oils by cathodic stripping potentiometry (CSP). Agricultural Food Chemistry 51(19): 5598-5601.

EFSA (2015). Scientific Opinion on Dietary Reference Values for vitamin A. In: European Food Safety Authority Panel on Dietetic Products, Nutrition and Allergies). EFSA Journal. http://www.meyerscience.com/images/publikationen/extern/201411 EFSA Draft Scientific Opinion on Dietary Reference Values for vitamin A.pdf Retrieved February 21, 2021. 
724

725

726

727

728

729

730

731

732

733

734

735

736

737

738

739

740

741

742

743

744

745

746

747

748

749

750

751

752

753

754

755

756

757

758

759

760

761

EFSA (2016). Acute health risks related to the presence of cyanogenic glycosides in raw apricot kernels and products derived from raw apricot kernels. European Food Safety Authority, 14(4) 4424-4462.

Eka, H.D., Tajul Aris, Y., and Wan Nadiah, W.A. (2010). Potential use of Malaysia rubber (Hevea brasiliensis) seed as food, feed and biofuel .International Food Research Journal, 17: 527-534.

Embaby, H. E. S. (2010). Effect of soaking, dehulling and cooking methods on certain anti-nutrients and in vitro protein digestibility of bitter and sweet lupin seeds. Food Science and Biotechnology, 19(4): 1055-62.

Eyarkai, V.N., Chandrasekar, V. and Karthikeyan, S. (2017). Value addition of grains using solid state fermentation. Nutrition and Food Science International Journal 3(4): 555619.

Essack, H., Odhay, B. and Mellem, J. J. (2017). Screening of traditional South African leafy vegetables for selected anti-nutrient factors before and after processing. Food Science and Technology, 3: 462-471.

FAO, IFAD, UNICEF, WFP \& WHO (2020). In Brief to The State of Food Security and Nutrition in the World 2020. Transforming food systems for affordable healthy diets. Rome, FAO.

FAOSTAT (2019). Food and Agriculture Organization of the United Nations. http://fao.org/faostat/en/\#data/QC Accessed February 05, 2021.

FAO/WHO (2001). Human Vitamin and Mineral Requirements. Reports of a joint FAO/WHO expect consultation. Food and Nutrition Division, FAO, Rome. Pp. 223-230.

FAO/WHO (2011). Cyanogenic Glycosides. Evaluations of Joint FAO/WHO Expert Committe on Food Additives (JECFA). Food and Nutrition Division, FAO, Rome. Pp. 202-230.

Farr, H.M., Donkoh, A., Boateng, M.K. \& Mensah, K.B. (2019). Evaluation of methods of processing rubber seed meal in terms of chemical composition and energy value. Livestock Research for Rural Development, 31(6) http://www.Irrd.org//rrd31/6/armdo31093.html Accessed February 5, 2021.

Fawole, F.J., Sahu, N.P., Jain, K.K., Gupta, S., Shamna, N., Phulia, V. \& Prabu, D.L. (2016a). Nutritional evaluation of protein isolate from rubber seed in the diet of Labeo rohita: Effects on growth performance, nutrient utilization, whole body composition and metabolic enzymes activity. Animal Feed Science and Technology, 219: 189-199.

Fawole, F.J., Sahu, N.P., Jain, K.K., Gupta, S. \& Shamna, N.(2016b). Protein isolate from rubber seed meal: Preparation and evaluation. J. Exp. Zool. India, 19(2): 677-681. 
762 Feng, D., Shen, Y. and Chavez, E.R. (2003). Effectiveness of different processing

763

764

765

766

767

768

769

770

771

772

773

774

775

776

777

778

779

780

781

782

783

784

785

786

787

788

789

790

791

792

793

794

795

796

797 methods in reducing hydrogen cyanide content of flaxseed. Journal of the Science of Food and Agriculture, 83: 836-841.

Finglas, P. (2000). Dietary reference intakes for Thiamine, Riboflavin, Niacin, Vitamin $\mathrm{B}_{6}$, Pantothenic acid, Biotin and Choline. Trends in Food Science and Technology 11(8): 296-297.

Gemede, H. F. and Ratta, N. (2014). Antinutritional factors in plant foods: potential health benefits and adverse effects. International Journal of Nutrition and Food Science, 3(4): 284-289.

Gokoglu, N., Yerlikaya, P. and Cengiz, E. (2004). Effects of cooking methods on the proximate composition and mineral contents of rainbow trout (Oncorhynchus mykiss). Food Chemistry, 84(1): 19-22.

GucluUstundag, O. and Mazza, G. (2007). Saponins: properties, applications and processing. Critical Reviews in Food Science and Nutriition, 47: 231-258.

Heaney, R. P. (2012). Phosphorus. In: Present knowledge in nutrition. (10 ${ }^{\text {th }}$ edition). Erdman, J. W., Macdonald, I. A., Zeisel, S. H. (eds.). Wiley Blackwell, Washington DC. Pp. 447-458.

Henriquez, C., Almonacids, C. I., Valenzuela, T, Araya, M., Cabezas, L., Simpson, R. and Speisky, H. (2010). Determination of Antioxidant capacity, total Phenolic content and mineral composition of different fruit tissue of 5 apple cultivars grown in Chile. Chilean Journal of Agricultuural Research, 70(4):523-536.

Hossain, E., Karim, M. H., Alam, S. \& Nath, S. K. (2015). Nutritive value of Rubber seed (Hevea brasiliensis). Online J. Anim. Feed Res. 5(1): 18-21.

Ibeabuchi, J.C., Olawuni, I.A., Iheagwara, M.C., Ojukwu, M. and Ofoedu, C.E. (2014). Microbial and sensory evaluation of iru and ogiri-isi as compared with commercial ogiri samples. International Journal of Innovative Research and Studies 3(9): 162-178.

Ihediohanma, N.C., Ofoedu, C.E., Ojimba, N.C., Okafor, D.C. and Adedokun, A.O. (2014). Comparative effect of milling methods on the proximate composition and functional properties of cowpea (Vigna unguiculata). International Journal of Life Sciences 3(4): 170-177.

Institute of Medicine (2000). Dietary Reference intakes for vitamin C, vitamin E, selenium and carotenoids. National Academic Press, Washington DC. Pp. 200298.

Institute of Medicine. (2010). Dietary Reference intakes for calcium and vitamin $D$. National Academy press, Washington DC. Pp. 67-98. 
798

799

800

801

802

803

804

805

806

807

808

809

810

811

812

813

814

815

816

817

818

819

820

821

822

823

824

825

826

827

828

829

830

831

832

833

834

Josipovic, A., Sudar, R., Sudaric, A., Jurkovic, V., Kocar, M. M. and Kulundzic, A. M. (2016). Total Phenolic and total flavonoids content variability of soy bean genotypes in eastern Croatia. Croatia Journal of Food Science and Technology, 8(2): 60-65.

Khan, M., Sharif, M., Sarwar, M and Arnean, S. (2010). Chemical composition of different varieties of linseed. Pakistan Veterinary Journal, 1(1): 30-45.

Kirkland, J. B. and Meyer-Ficca, M. (2016). Niacin. Advanced Nutrition 7(3): 556-558.

Kubala, J. (2018). Vitamin A: benefits, Deficiency, toxicity and more. Healthline. Retrieved from https://www.healthline.com/nutriiton/vitamin-a\#deficiency. Accessed March 11 th 2020.

Kubala, J. (2019). 7 Science-based Health Benefits of Selenium. Retrieved from http://www.healthline.com/nutrition/selenium-benefits\#2-May-reduce-your-risk-ofcertain-cancers. Accessed February 21, 2021.

Kumar, V., Sinha, A. K., Makkar, A. P. S. and Klaus, B. (2010). Dietary roles of phytate and phytase in human nutrition: a review. Food Chemistry, 120(4): 945-959.

Kurek, J. (2019). Alkaloids - Their Importance in Nature and for Human Life. IntechOpen. Retrieved from https://www.intechopen.com/books/alkaloids-theirimportance-in-nature-and-human-life/introductory-chapter-alkaloids-theirimportance-in-nature-and-for-human-lifel. Accessed January 18, 2020.

Lalabe, B. C., Olusiyi, J. A. \& Afolabi, K. D. (2017). Effects of Soaking on the Nutritive Value of Raw Full Fat Rubber (Hevea Brasiliensis) Seed. Nigerian Journal of Agriculture, Food and Environment 13(2): 78-82.

Lukman, A. O., Nurul, H. and Connie, F. K. (2018). Potential utilization of rubber seed meal as feed and food. Internal Journal of Engineering and Technology, 7(4):6471.

Ma, X., Hu, J., Shang, Q., Liu, H. \& Piao, X. (2019). Chemical composition, energy content, and amino acid digestibility in cottonseed meals fed to growing pigs. Journal of Applied Animal Research 47(1): 280-288.

Maliki, M. and Ifijen, I. H. (2020). Extraction and characterization of rubber seed oil. International Journal of Scientific Engineering and Science, 4(6): 24-27.

Mark, M. (2020). Understanding Pulse anti-nutrients. American Oil Chemist Society. Retrieved from https://www.aocs.org/stay-informed/inform-magazine/featuredarticles/understanding-pulse-anti-nutrientsjanuary-2020?sso=True. Accessed $5^{\text {th }}$ May, 2020.

Muhammad, F. S., Muhammad, H. S., Muhammad, S., Niaz, A. Q. and Safia, M. (2013). The role of oilseeds nutrition in human health. A critical review. Journal of Cereals and Oilseeds, 4(8):97-100.

Peer) reviewing PDF | (2020:10:54065:2:0:NEW 22 Mar 2021) 
835 Mujic, I., Sertovic, E., Jokie, S., Saric, Z., Alibabic, V., Vidovic, S. and Zivkovic, J.

836

837

838

839

840

841

842

843

844

845

846

847

848

849

850

851

852

853

854

855

856

857

858

859

860

861

862

863

864

865

866

867

868

869

870

871 (2011). Isoflavone content and antioxidant properties of soybean seeds. Croatia Journal of Food Science and Technology, 3(1): 16-20.

Newman, T. (2017). All you need to know about beta carotene. Available on http://www.medicalnewstoday.com/articles/2527581/ Accessed on October 2, 2020.

$\mathrm{NIH}$ (2020). Vitamin E: fact sheet for health professionals. National Institute of Health. Retrieved from https://ods.od.nih.gov/factsheets/vitaminE-HealthProfessional/. Accessed March 11, 2020.

Nwosu, J.N., Odimegwu, N., Ofoedu, C.E., Ibeabuchi, J.C., Olawuni, I.A. and Ikeli, K. (2013). Evaluation of the proximate and antinutritional qualities of Ihu (Dioscorea dumentorum). International Journal of Life Sciences 3(3): 92-104.

Obiakor-Okeke, P. N. (2014). Comparative evaluation of chemical and functional properties of some lima bean varieties (Phaseolus lunatus) consumed in Arondizuogu, Imo State, Nigeria. Journal of Food and Nutrition Sciences, 2(4): 168-172.

Ofoedu, C.E., Osuji, C.M., Omeire, G.C., Ojukwu, M., Okpala, C.O.R., and Korzeniowska, M. (2020). Functional properties of syrup from malted and unmalted rice of different varieties: A comparative study. Journal of Food Science 85(10): 3081-3093.

Ogbemudia, R. E., Nnadozie, B. C. and Anuge, B. (2018). Mineral and proximate composition of soya bean. Asian Journal of Physical and Chemical Sciences, 4(3): 1-6.

Okwu, D. E. and Ndu, C. U. (2006). Evaluation of the phytonutrients, mineral and vitamin contents of some variaties of yam (Dioscorea spp). International Journal of Molecular Medicine and Advanced Science, 293: 199-203.

Okwu, D. E. and Orji, B. O. (2007). Phytochemical composition and nutritional quality of Glycine max and Vigna unguiculata (L.) walp. Amerian Journal of Food Technology, 2: 512-520.

Okwulehie, I. C., Alozie, V. C., Ikechukwu, G. C. and Nwokeocha, O. W. (2017). Effect of extraction solvents on bioactive compounds and antimicrobial activities of 2 varieties of Garcinia kola (heckel) obowo 02 (soft and less bitter) and obowo 03 (hard and very bitter). Pharmaceutical and Biosciences Journal, 5(6): 20-25.

Onwuka, G. I. (2018). Food Analysis and Instrumentation-theory and practice. (2 $2^{\text {nd }}$ edition). Naphtali Prints, Lagos Nigeria. Pp. 365-390.

Onwurah, I. N. E., Otitoju, O., Njoku, O. U., Okafor, F. C. and Obidimegwu, C. (2010). Nutritional value of rubber seed flour for poultry feed-stock, using adult insect 
872

873

874

875

876

877

878

879

880

881

882

883

884

885

886

887

888

889

890

891

892

893

894

895

896

897

898

899

900

901

902

903

904

905

906

907

908

909

Tribolium castaneum as a model. Archives of Applied Science Research, 2(5):422-428.

Osuji, C.M., Ofoedu, C.E. and Ojukwu, M. (2019). Proximate, malting characteristics and grain quality properties of some Nigerian rice of different varieties. Research Journal of Chemical Sciences, 9(2): 1-10.

Panche, A. N., Diwan, A. D. and Chandra, S. R. (2016). Flavonoids: an overview. Journal of Nutritional Science, 5(47): 66-78.

Patterson, C. A., Curran, J. and Der, T. (2016). Effect of processing on anti-nutrient compound in pulses. Cereal Chemistry, 94(1): 32-41.

Pohl, H. R., Wheeler, J. S. and Murray, E. H. (2013). Interrelations between essential metal ions and human diseases. Sigel, A., Sigel, H. and Sigel, R (eds.). Metal lons in Life Sciences, 13: 29-47.

Popova, A. and Mihaylova, D. (2019). Anti-nutrients in plant-based foods: a review. The Open Biotechnology Journal, 13: 68-76.

Redondo, N. Nava, E., Gomez-Martinez, S., Diaz-Prieto, L.E. \& Marcos, A. (2019). Diet, Nutrition and the immune system. In: Encyclopedia of food security and sustainability. Pasquale, F., Berry, E.M. \& Anderson,. J.R. (eds.). Pp. 250-255. Elsevier.

Reis-Giada, M. (2013). Food Phenolic compounds-main classess, sources and their antioxidant power, oxidative stress and chronic degenerative diseases- $A$ role for antioxidants. IntechOpen. Retrieved from https://www.intechopen.com/books/oxidative-stress-and-chronic-degenerativediseases-a-role-for-antioxidants/food-phenolic-compounds-main-classessources-and-their-antioxidantpower. Accessed May 28th, 2020.

Rude, R. K. (2014). Magnesium. In: Modern Nutrition in Health and Disease.(11 th edition). Ross, A.C., Caballero, B., Cousins, R. J., Tucker, K. L. and Ziegler, T. R. (eds). Lippincott Williams and Wilkins, Baltimore, Maryland. Pp. 159-175.

Russo, R. and Reggiani, R. (2016). Evaluation of protein and antinutritional compounds content in meal from seven flax varieties. Journal of Global Agriculture and Ecology, 6(3): 182-188.

Sachdev, H.P.S and Shah, D. (2020). Vitamin B deficiencies and excess. In: Nelson Textbook of Pediatrics. Kliegman, R.M., St. Geme, J.W., Blum, N.J., Shah. S.S., Tasker, R.C., Wilson, R.M. eds.. 21 ${ }^{\text {st }}$ ed. Philadelphia, PA: Elsevier, Chap 62.

Sayer, J. (2018). 70 health reasons to eat more flax seed. Food Evolution Network. Retrieved from https://www.google.com/amp/s/foodrevolution.org/blog/healthbenefits-flaxseed/amp. Accessed April 22nd, 2020.

Scott, K. J. and Rodriquez, A. D. (2000). Pro-vitamin A carotenoid conversion factors: retinol equivalents, fact or fiction? Food Chemistry, 69(2): 125-127. 
910 Schrenk, D., Bignami, M., Bodin, L., Chipman, J.K., del Mazo, J., Grasl-Kraupp, B.,

911

912

913

914

915

916

917

918

919

920

921

922

923

924

925

926

927

928

929

930

931

932

933

934

935

936

937

938

939

940

941

942

943

944

945

946

947 Hogstrand, C., Hoogenboom, L., Leblanc, J.C., Nebbia, C.S., Nielsen, E., Ntzani, E., Petersen, A., Sand, S., Vleminckx, C., Wallace, H., Benford, D., Brimer, L., Mancini, F.R., Metzler, M., Viviani, B., Altieri, A., Arcella, D., Steinkellner, H. and Schwerdtle, T. (2019). Evaluation of the health risks related to the presence of cyanogenic glycosides in foods other than raw apricot kernels. EFSA Journal, 17(4): 5662-5678.

Sharma, B. B., Saha, R. K. \& Saha, H. (2014). Effects of feeding detoxified rubber seed meal on growth performance and haemato-logical indices of Labeo rohita (Hamilton) fingerlings. Animal Feed Science and Technology 193: 84-92.

Singh, H.K. A/P G., Yusup, S. \& Wai, C.K. (2016). Physicochemical properties of crude rubber seed oil for biogasoline production. Procedia Engineering, 148: 426-431.

Siti, H. M. S., Lee, N. Y., Wan, N. W. K., Zuhaili, I. and Abd-Talib, N. (2013). Omega 3 emulsion of Rubber (Hevea brasiliensis) seed oil. Agricultural Sciences, 4(5): 8489.

Spritzler, F. (2017). Oxalate (Oxalic Acid): Good or Bad? Healthline. Retrieved from https://www.healthline.com/nutrition/oxalate-good-or-bad. Accessed $5^{\text {th }}$ May, 2020.

Sokrab, A.M, Ahmed, I.A.M. and Babiker, E.E. (2014). Effect of fermentation on antinutrients, and total and extractable minerals of high and low phytate corn genotypes. J. Food Sci. Technol. 51(10): 2608-2615.

Suprayudi, M. A., Inara, C., Ekasari, J., Priyoutomo, N., Haga, Y., Takeuchi, T. \& Satoh, S. (2015). Preliminary nutritional evaluation of rubber seed and defatted rubber seed meals as plant protein sources for common carp Cyprinus carpio L. juvenile diet. Aquaculture Research 46(12): 2972-2981.

Syhruddin, E., Herawaty, R. \& Ningrat, R.W.S. (2014). Effect of substitution of leaves and seeds of rubber (Hevea brasiliensis) fermentation with soybean meal on the performance of broilers. Pakistan Journal of Nutrition, 13(7): 422-426.

Tang, J.W., Sun, H., Yao, X.H., Wu, Y.F., Wang, X. \& Feng, J. (2012). Effects of replacement of soybean meal by fermented cottonseed meal on growth performance, serum biochemical parameters and immune function of yellowfeathered broilers. Asia-Aust. J. Anim. Sci. 25(3): 393-400.

Udo, M. D., Ekpo, U. and Ahamefule, F. O. (2018). Effects of processing on the nutrient composition of rubber seed meal. Journal of the Saudi Society of Agricultural Sciences, 17(3):297-301.

Urbano, G., Lopez-Jurado, M., Aranda, P., Vidal-Valverde, C., Tenorio, E. and Porres, J. (2000). The role of phytic acid in legumes: anti-nutrient or beneficial function? Journal of Physiology and Biochemistry, 56: 283-294. 
948

949

950

951

952

953

954

955

956

957

958

959

960

961

962

963

964

965

966

967

968

969

970

971

972

973
Useh, M. U., Adebiyi, A. B. and Dauda, M. S. (2017). Proximate composition, phytoconstituents and mineral contents of soybean (Glycine max) flour grown and processed in northern Nigeria. Advances in Applied Sciences, 2(4): 48-53.

VanEys, J. A., Offner, A. and Bach, A. (2004). Chemical Analysis. Manual of Quality Analysis for soybean products in the feed industry. American Soybean Association. Pp. 1-15.

Wessling-Resnick, M. (2014). Iron. In: Modern Nutrition in Health and Disease.(11 ${ }^{\text {th }}$ edition). Ross, A.C., Caballero, B., Cousins, R. J., Tucker, K. L. and Ziegler, T. R. (eds). Lippincott Williams and Wilkins, Baltimore, Maryland. Pp. 176-188.

WHO. (2012a). Guideline: Potassium intake for adults and children. WHO Press, Geneva, Switzerland. Pp. 10-16.

WHO. (2012b). Guideline: Sodium intake for adults and children. WHO Press, Geneva, Switzerland. Pp. 10-16.

Widyarani, Coulen, S.C.W., Sanders, J.P.M. \& Bruins, M.E. (2017). Valorisation of proteins from rubber tree. Waste Biomass, 8: 1027-1041.

Winther, K.H., Wichman, J.E., Bonnema, S.J. and Hegedüs, L. (2017). Insufficient documentation for clinical efficacy of selenium supplementation in chronic autoimmune thyroiditis, based on a systematic review and metaanalysis. Endocrine. 55(2): 376-385.

Yalcin, S. and Basman, A. (2015). Effects of infra red treatment on urease, trypsin inhibitor and lipoxygenase activities of soybean samples. Food Chemistry, 169: 203-210,

Yusup, S. and Khan, M. (2010). Basic properties of crude rubber seed oil and crude palm oil blend as a potential feedstock for biodiesel production with enhanced cold flow characteristics. Biomass and Bioenergy, 34(10): 1523-1526 


\begin{tabular}{|c|c|}
\hline \multicolumn{2}{|c|}{ ABBREVIATION } \\
\hline RRSM & Raw rubber seed meal \\
\hline BRSM & Boiled rubber seed meal \\
\hline FRSM & Fermented rubber seed meal \\
\hline $\mathrm{Mg}$ & Magnesium \\
\hline $\mathrm{P}$ & Phosphorus \\
\hline $\mathrm{Ca}$ & Calcium \\
\hline $\mathrm{Fe}$ & Iron \\
\hline $\mathrm{Zn}$ & Zinc \\
\hline K & Potassium \\
\hline $\mathrm{Na}$ & Sodium \\
\hline $\mathrm{Mn}$ & Manganese \\
\hline $\mathrm{Pb}$ & Lead \\
\hline $\mathrm{Se}$ & Selenium \\
\hline Vit B1 & Thiamine \\
\hline Vit. B2 & Riboflavin \\
\hline Vit B3 & Niacin \\
\hline Vit C & Ascorbic acid \\
\hline Vit E & Tocopherol \\
\hline $\mathrm{HCN}$ & Hydrogen cyanide \\
\hline TI & Trypsin inhibitor \\
\hline RDA & Recommended dietary allowance \\
\hline RDI & Recommended daily intake \\
\hline
\end{tabular}


Figure 1

Figure 1: Schematic diagram of experimental program. The resultant seed meal were categorized as raw rubber seed meal (RRSM), boiled rubber seed meal (BRSM) and fermented rubber seed meal (FRSM).

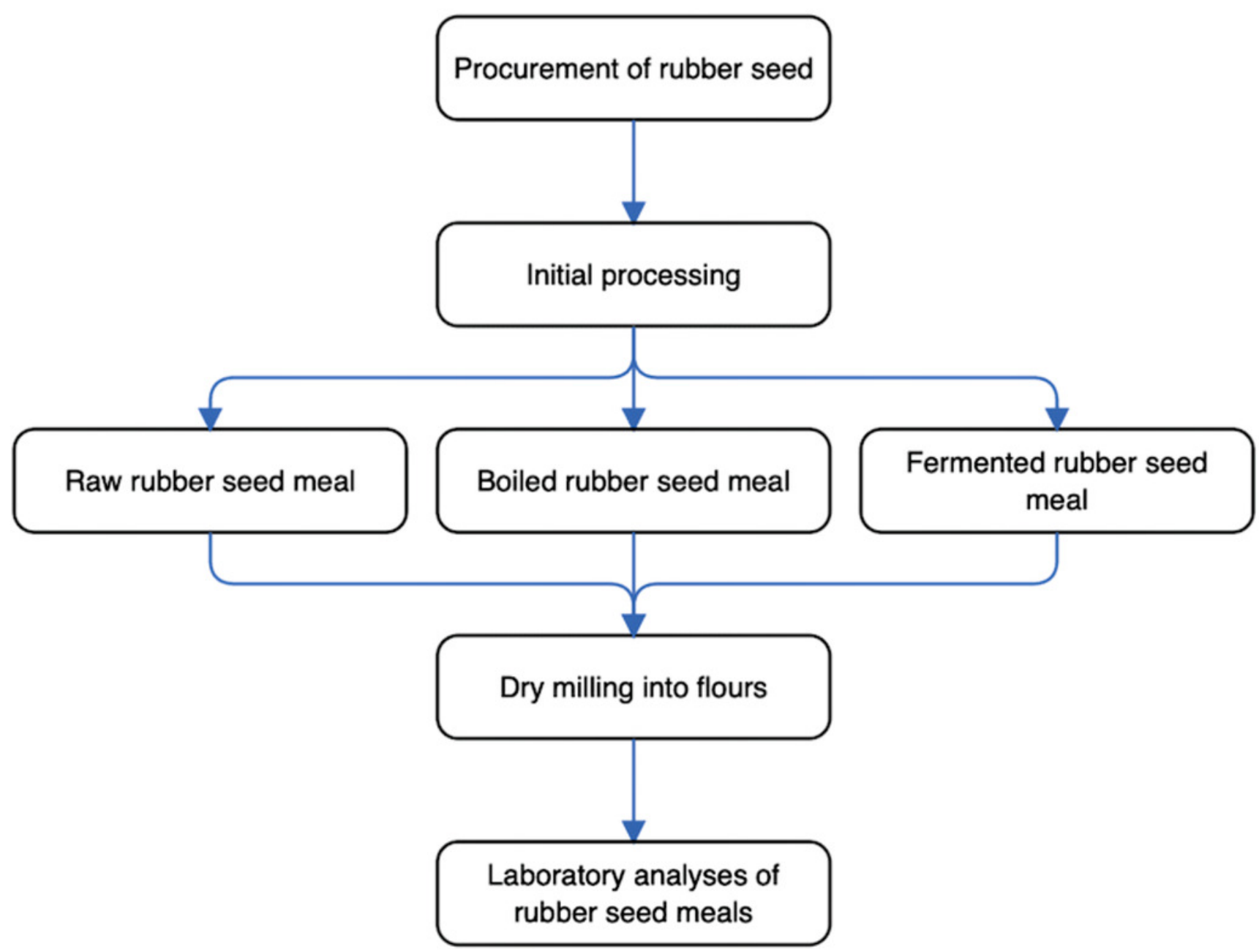


Figure 2

Figure 2: The schematic diagram for the production process to generate the rubber seed meals. The processes that the rubber seed undergo, to bring about raw, boiled and fermented rubber seed meal can be seen. 


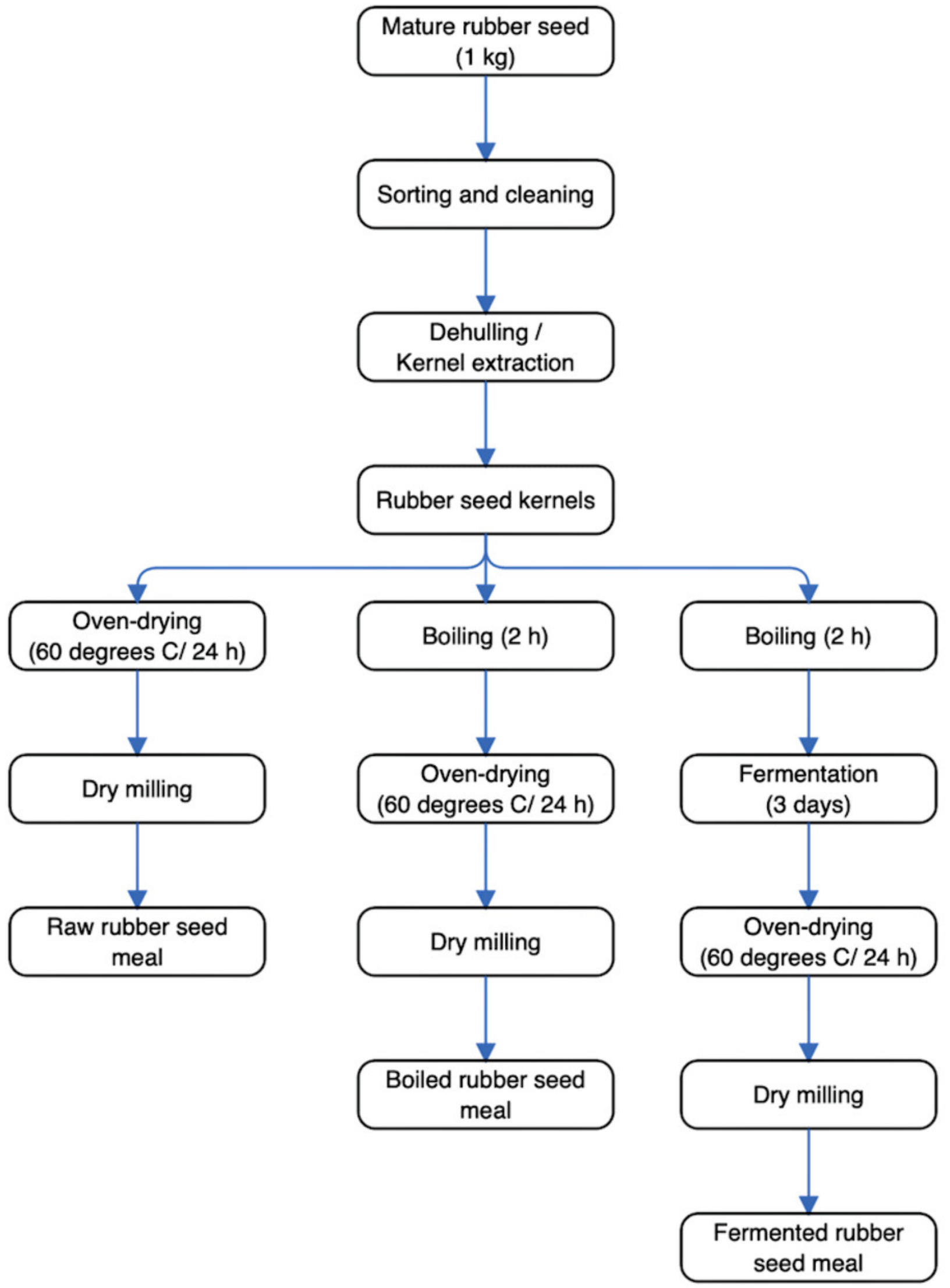




\section{Table 1 (on next page)}

Variations in anti-nutrients and phytochemical composition of rubber seed meal sample

Means with same superscripts in the same row are not significantly different ( $\left.p^{\prime} 0.05\right) ; *$ Data of the current study; ${ }^{* *}$ Published references Key: RRSM = Raw rubber seed meal; BRSM = Boiled rubber seed meal; FRSM = Fermented rubber seed meal 
1 Table 1: Variations in anti-nutrients and phytochemical contents of rubber seed 2 meal samples

\begin{tabular}{llccc}
\hline Parameters $\quad{ }^{*}$ RRSM & *BRSM & *FRSM & $\begin{array}{c}{ }^{*} \text { Safety } \\
\text { limit } \\
(\mathrm{mg} / 100 \mathrm{~g})\end{array}$ & $\begin{array}{c}{ }^{* *} \text { Sources for } \\
\text { the safety } \\
\text { limits }\end{array}$
\end{tabular}

\begin{tabular}{llllll}
\hline $\begin{array}{l}\text { Phytate } \\
(\mathbf{m g} / \mathbf{1 0 0 g})\end{array}$ & $19.62^{\mathrm{a}} \pm 0.22$ & $8.82^{\mathrm{b}} \pm 0.10$ & $6.97^{\mathrm{c}} \pm 0.10$ & $<25$ & $\begin{array}{l}\text { Abdoulaye et } \\
\text { al., (2011) }\end{array}$
\end{tabular}

$\begin{array}{llllll}\begin{array}{l}\text { Oxalate } \\ (\mathbf{m g} / 100 g)\end{array} & 13.26^{\mathrm{a}} \pm 0.02 & 7.54^{\mathrm{b}} \pm 0.09 & 3.36^{\mathrm{c}} \pm 0.06 & <10 & \text { Mark (2020) } \\ \begin{array}{l}\text { Tannin } \\ (\mathbf{m g} / \mathbf{1 0 0 g})\end{array} & 8.98^{\mathrm{a}} \pm 0.06 & 2.21^{\mathrm{b}} \pm 0.06 & 0.92^{\mathrm{c}} \pm 0.06 & 12 & \begin{array}{l}\text { Ndie \& Okaka } \\ (2018)\end{array}\end{array}$

$\begin{array}{llrl}\text { Saponin } & 4.91^{\mathrm{a}} \pm 0.01 & 2.39^{\mathrm{b}} \pm 0.01 & 1.60^{\mathrm{c}} \pm 0.04\end{array}$

$\begin{array}{llllll}\mathbf{H C N} & 12.41^{\mathrm{a}} \pm 0.06 & 4.71^{\mathrm{b}} \pm 0.16 & 1.97^{\mathrm{c}} \pm 0.10 & 1 & \text { FAO/WHO } \\ (\mathbf{m g} / \mathbf{1 0 0 g}) & & & & & (2011)\end{array}$

$\mathrm{Tl}$ (TiU/mg) $\quad 8.43^{\mathrm{a}} \pm 0.06 \quad 3.20^{\mathrm{b}} \pm 0.14 \quad 0.97^{\mathrm{c}} \pm 0.17$
Alkaloids
$4.54^{\mathrm{a}} \pm 0.06$
$1.80^{\mathrm{b}} \pm 0.014$
$0.97^{c} \pm 0.06$ (mg/100g)
Phenols
$2.77^{a} \pm 0.06$
$1.10 \pm 0.02$
$0.50^{\mathrm{c}} \pm 0.02$
(mgGAE/g)

Flavonoids $\quad 60.00^{\mathrm{a}} \pm 3.53 \quad 40.00^{\mathrm{b}} \pm 0.53 \quad 52.50^{\mathrm{a}} \pm 0.00$ (mgQE/100g)

3 Means with same superscripts in the same row are not significantly different $(p>0.05)$;

4 Data of the current study; ${ }^{* *}$ Published references

5 Key: RRSM = Raw rubber seed meal; BRSM = Boiled rubber seed meal; FRSM =

6 Fermented rubber seed meal 


\section{Table 2 (on next page)}

Variations in mineral contents of rubber seed meal samples

Means with same superscripts in the same row are not significantly different $\left(p^{>} 0.05\right) ; *$ Data of the current study; ${ }^{* *}$ Published references Key: RRSM = Raw rubber seed meal; BRSM = Boiled rubber seed meal; FRSM = Fermented rubber seed meal, ND = Not Detected 
1 Table 2: Variations in mineral contents of rubber seed meal samples 2

\begin{tabular}{|c|c|c|c|c|c|}
\hline $\begin{array}{l}\text { Mineral } \\
\text { element }\end{array}$ & $\begin{array}{c}{ }^{*} R R S M \\
(\mathrm{mg} / 100 \mathrm{~g})\end{array}$ & $\begin{array}{c}{ }^{*} \text { BRSM } \\
(\mathrm{mg} / 100 \mathrm{~g})\end{array}$ & $\begin{array}{c}\text { *FRSM } \\
(\mathrm{mg} / 100 \mathrm{~g})\end{array}$ & $\begin{array}{l}{ }^{* *} \text { Safety } \\
\text { limit } \\
\text { (mg/100g) }\end{array}$ & $\begin{array}{l}{ }^{* *} \text { Sources } \\
\text { for the } \\
\text { safety limits }\end{array}$ \\
\hline Magnesium & $119.03^{b} \pm 0.88$ & $112.15^{c} \pm 0.45$ & $122.72^{a} \pm 1.50$ & $220-260$ & $\begin{array}{l}\mathrm{FAO} / \mathrm{WHO} \\
(2001)\end{array}$ \\
\hline Phosphorus & $225.74^{b} \pm 0.60$ & $220.72^{c} \pm 1.35$ & $228.93^{a} \pm 0.54$ & 700 & $\begin{array}{l}\text { FAO/WHO } \\
(2001)\end{array}$ \\
\hline Calcium & $205.08^{a} \pm 3.72$ & $193.57^{b} \pm 0.00$ & $205.13^{a} \pm 0.33$ & 1000 & $\begin{array}{l}\text { FAO/WHO } \\
(2001)\end{array}$ \\
\hline Iron & $5.88^{b} \pm 0.23$ & $4.95^{c} \pm 0.04$ & $7.86^{a} \pm 0.23$ & $8-18$ & $\begin{array}{l}\text { FAO/WHO } \\
(2001)\end{array}$ \\
\hline Zinc & $1.29^{\mathrm{b}} \pm 0.06$ & $0.99^{c} \pm 0.08$ & $1.56^{a} \pm 0.00$ & $8-11$ & WHO (2012a) \\
\hline Potassium & $795.28^{a} \pm 1.60$ & $778.10^{\mathrm{b}} \pm 5.05$ & $800.16^{a} \pm 1.56$ & 3500 & WHO (2012a) \\
\hline Sodium & $10.21^{b} \pm 0.02$ & $9.84^{c} \pm 0.31$ & $10.52^{\mathrm{a}} \pm 0.04$ & $<2000$ & WHO (2012b) \\
\hline Manganese & $0.41^{a} \pm 0.01$ & $0.35^{b} \pm 0.01$ & $0.39^{\mathrm{ab}} \pm 0.01$ & $1.8-2.3$ & $\mathrm{NIH}(2020)$ \\
\hline Lead & $0.12^{\mathrm{a}} \pm 0.00$ & $0.07^{c} \pm 0.01$ & $0.10^{\mathrm{b}} \pm 0.01$ & & \\
\hline Selenium & $0.03^{a} \pm 0.00$ & $0.02^{\mathrm{a}} \pm 0.00$ & $0.00^{b} \pm 0.00$ & 0.055 & $\begin{array}{l}\text { Institute of } \\
\text { Medicine } \\
(2000)\end{array}$ \\
\hline Nickel & ND & ND & ND & & \\
\hline
\end{tabular}

3 Means with same superscripts in the same row are not significantly different $(p>0.05) ;{ }^{*}$ Data of

4 the current study; ${ }^{* *}$ Published references

5 Key: $\mathrm{RRSM}=$ Raw rubber seed meal; $\mathrm{BRSM}=$ Boiled rubber seed meal; FRSM = Fermented

6 rubber seed meal, ND $=$ Not Detected 


\section{Table 3(on next page)}

Variations in vitamin composition $(\mathrm{mg} / 100 \mathrm{~g})$ of rubber seed meal sample

Means with same superscripts in the same row are not significantly different ( $\left.p^{>} 0.05\right)$; * Data of the current study; ${ }^{* *}$ Published references Key: RRSM = Raw rubber seed meal; BRSM = Boiled rubber seed meal; FRSM = Fermented rubber seed meal 
1 Table 3: Variations in vitamin contents of rubber seed meal samples

2

\begin{tabular}{lccccc}
\hline Vitamin content & $\begin{array}{c}{ }^{*} \mathrm{RRSM} \\
(\mathrm{mg} / 100 \mathrm{~g})\end{array}$ & $\begin{array}{c}{ }^{*} \mathrm{BRSM} \\
(\mathrm{mg} / 100 \mathrm{~g})\end{array}$ & $\begin{array}{c}{ }^{*} \mathrm{FRSM} \\
(\mathrm{mg} / 100 \mathrm{~g})\end{array}$ & $\begin{array}{c}{ }^{* *} \mathrm{RDA} \\
(\text { Adults }) \\
(\mathrm{mg} / 100 \mathrm{~g})\end{array}$ & ${ }^{* *}$ RDA R (Adults)
\end{tabular}

B1 (Thiamin) $\quad 0.30^{\mathrm{a}} \pm 0.01 \quad 0.21^{\mathrm{b}} \pm 0.01 \quad 0.26^{\mathrm{a}} \pm 0.01 \quad 1.1-1.2 \quad$ Finglas $(2000)$

B2 (Riboflavin) $\quad 0.52^{\mathrm{a}} \pm 0.01 \quad 0.31^{\mathrm{c}} \pm 0.03 \quad 0.38^{\mathrm{b}} \pm 0.00 \quad 1.1-1.3 \quad$ Finglas $(2000)$

B3 (Niacin) $\quad 0.77^{\mathrm{a}} \pm 0.05 \quad 0.51^{\mathrm{b}} \pm 0.02 \quad 0.72^{\mathrm{a}} \pm 0.04 \quad 14-16 \quad \begin{aligned} & \text { Kirkland } \\ & \text { Meyer-Ficca, }\end{aligned}$ (2016)

$\begin{array}{llllll}\beta \text {-carotene } & 3.77^{\mathrm{a}} \pm 0.02 & 2.09^{\mathrm{c}} \pm 0.09 & 3.22^{\mathrm{b}} \pm 0.09 & 0.7-0.9 & \text { Kubala (2018) }\end{array}$

$\begin{array}{lllll}\text { Vitamin C } & 29.09^{a} \pm 0.52 \quad 10.03^{c} \pm 0.60 & 15.09^{b} \pm 0.4360 \quad \text { Institute of }\end{array}$ Medicine (2000)

$\begin{array}{llllll}\text { Vitamin E } & 8.90^{\mathrm{a}} \pm 0.32 & 5.92^{\mathrm{c}} \pm 0.23 & 7.46^{\mathrm{b}} \pm 0.04 & 15 & \mathrm{NIH}(2020)\end{array}$

5 Means with same superscripts in the same row are not significantly different ( $p>0.05)$;

6 Data of the current study; ${ }^{* *}$ Published references

7 Key: RRSM = Raw rubber seed meal; $B R S M=$ Boiled rubber seed meal; FRSM =

8 Fermented rubber seed meal 